\title{
The online shopping change the retail business model: A survey of the people use online shopping in China.
}

\author{
You Qinghe; Chen Wenyuan; Liu Kaiming \\ Business Administration; President University;Indonesia
}

\begin{abstract}
The Internet is a global communication medium that is increasingly being used as an innovative tool for marketing goods and services. The Internet has added a new dimension to the traditional nature of retail shopping. The internet offers many advantages over traditional shopping channels and the medium is a competitive threat to traditional retail outlets. Globally, consumers are rapidly adopting Internet shopping and shopping online. It is becoming popular in China. If online marketers and retailers know and understand the factors affecting consumers' buying behavior, they can further develop their marketing strategies to attract and retain customers.

There is a conceptual gap in the marketing literature as there has been very limited published research on the factors influencing consumers' choices between online shopping and traditional shopping in China. This study seeks to fill this conceptual gap in the context of online shopping by identifying the key factors influencing Chinese consumers' online shopping behavior

This research offers some insights into the links between e-shopping and consumers' decisions to shop or not shop online. This information can help online marketers and retailers to develop appropriate market strategies, make technological advancements, and make the correct marketing decisions in order to retain current customers and attract new customers. Moreover, managerial implications and recommendations are also presented.
\end{abstract}

Keywords: Online Shopping, Electronic Market, China

\section{Introduction}

In the past decade, the rapid development of e-commerce in China has become a major trend. China's retail industry has undergone tremendous changes. From the original traditional retail to the current e-commerce, China's logistics system is improving. It is making the network of traditional retail caused a huge impact. (You, 2013)

The Internet in current form is primarily a source of communication, information and entertainment but increasingly the Internet is also a vehicle for commercial transactions. (James, Internet) Internet commerce involves the sales and purchases of products and services over the Internet. This new type of shopping mode has been called online shopping, e-shopping; Internet shopping, electronic shopping and web based shopping.

The Internet Age coming, the new e-commerce business model emerged. When the beginning, we already showing strong momentum of development. In the field of home appliances, electronic commerce has developed rapidly, Like GOME, SUNING as a leader in the retail industry, they set up their own e-commerce systems to seize the market. SUNING stores are set up China's first chain of the enterprise, in this Internet revolution and rapid response, its e-commerce front - SUNING Online Shopping Mall has been put into operation E-commerce is a huge construction project that requires working on several fronts. In this paper, we will discuss the case of e-commerce in China. (DU, 2012)

With the optimal allocation of resources and improvement of facilities, the adaptability of the online retail business model will become increasingly strong retail network. It will be developed to a new height. According to iResearch report concludes that online shopping has become one of the ways the mainstream consumer society. According to the average annual growth rate in recent years and the rapid growth of online shopping. 2012, China's online shopping market exceeded one trillion Yuan. It mark the online shopping market will account for $8 \%$ of total retail sales of social consumer goods share. Recalling the history of retail development appeared in the grocery store. The grocery store to professional management, just sell one or a few goods. It becomes a specialty store. Another small part of grocer through capital accumulation Types of goods to sell more and more into a department store. Retail department stores accounted for only less than $1 \%$ total number of enterprises, Accounted for $10 \%$ of total retail sales. With a larger scale lower prices to go down the route, there were the supermarket form Discount stores. like Wal-Mart retail monopoly position occupied Shop online and offline shop has similar origins - grocery store. The earliest open shop it out of curiosity, it do not put things into their own online selling. With the rise of online transactions, these people can also be found in open shop to make money, with the rise of online transactions, these people can also be found in open shop to make money, 
so start thinking about how to earn more, and they will specialize in online or limited to become the specialty store. But the shop does not go like the stores - supermarkets - Wal-Mart. Because the online retailers don't need to get low-cost advantages Shop is characterized by flexibility- "while online retailers often from a single look weak, it is impossible, and Wal-Mart retail 'boss battle, but they play their own network of relationships and expertise, or can get centralized purchasing Wal-Mart lower prices, or to provide a personalized service. (Finance week paper- iResearch, 2012)

China Internet Network Information Center (CNNIC) released the 21st China Internet Development Statistics Report "shows that as of December 31, 2007, the total number of Internet users in China reached 210 million people. Network reaches 55 million consumers. According to iResearch and Taobao joint research, the 2007, China's online shopping market total turnover reached 59.4 billion RMB to 31.2 billion RMB in 2006 , an increase of 90.4 percent, while per capita consumption also showed a steady growth trend,724 RMB in 2006 and 1,080 RMB in 2007, an increase of $49.2 \%$. By the Internet known consulting firm is looking Consulting released the 2006 China online shopping survey results show that the next few years, B2C online retail will remain rapid development stage. (CNNIC, 2010)

Monsuwe, Dellarert, and Ruyter(1999,p194) suggest five reasons that drive consumers to shop online. Firstly, consumers can use minimal time and effort to browse an entire product assortment by shopping online. Secondly, consumers can gain important information about companies, products and brands efficiently by using the Internet to help them make purchase decisions more accurately. Thirdly, when compared to traditional retail shopping, online shopping enables consumers to compare product features, price, and availability more efficiently and effectively. Fourthly, online shopping allows consumers to maintain their privacy when they buy sensitive products. Finally, online shopping can reduce consumers' shopping time, especially for those consumers whose times are perceived to be costly when they do brick-and-mortar shopping.

Summing up the appeal, and nowadays the Internet is more common, more people choose to buy their favorite products online. This is a new business model: e-commerce. However, no matter what the business, the customer is always a major factor. If we know the factors that affect the customer, we can better solve the problems of our business transactions. This can bring a lot of convenience to customers, while allowing companies to better operations.

\section{I.2 Problem Statement}

"An increasing number and variety of firms and organizations are exploiting and creating business opportunities on the Internet", (Liao, 2012) above mention statistics indicate the rapid growth in the field of virtual shopping. With this emerging field of shopping the interest of marketers is also increasing in studying what actually motivates consumers to shop online. Fierce competitions among online sellers have forced them to gain the competitive edge in the field of virtual shopping. Number of individuals opening online stores in China reached 13 million in 2010, more than double the number in 2007.

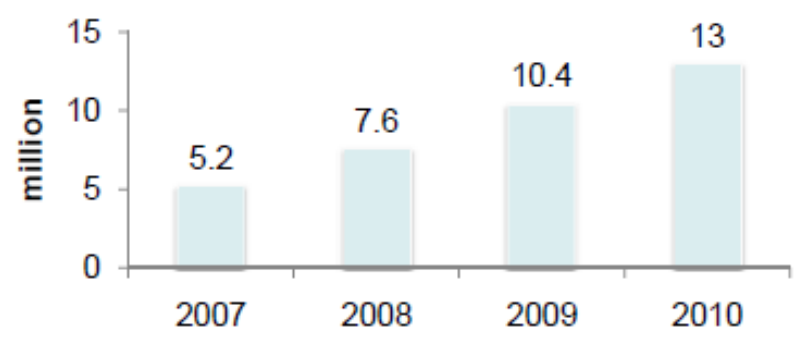

Figure 11 The Number of Individual Online shops 2007-2010

The source of material: China E-commerce Research Development Center, 2012

If we want to gain a competitive advantage in the marketplace, marketers need to know consumer psychology and behavior in the field of online shopping. Therefore, it is very important variable to analyze and identify the impact of consumers in order to grasp the needs of consumers shopping online.

A number of online retailers are now growing. Research shows that the world's Top25 retailers are doing business in China. Definitely, this figure will grow larger in the future. Since there are so many online retailers in China, the competition between them is fierce.

It is very important for retailers to identify what factors affect consumers to shopping online. In order to achieve the intention to buy, it contains a lot of factors that influence consumer online shopping. These factors are important in the competitive retail market. We need to make their products more compatible. Therefore, the main research questions are that:

Will the convenience, website design/feature, time saving and security have influence to the customers' purchasing intention towards online shopping? 


\section{I.3 Problem Identification}

In the research, when we use our literature study and survey method, we will try to get the answers for the following questions:

1. Will the convenient have the good effective to the customers' purchasing intention towards online shopping?

2. Will the website design/feature have the good effective to the customers` purchasing intention towards online shopping?

3. Will time saving have the good effective to the customers` purchasing intention towards online shopping?

4. Will security have the good effective to the customers` purchasing intention towards online shopping?

\section{I.4 Research Objectives}

Online shopping is increasing rapidly. On a global scale it is the most popular way to shop. However, online shopping has not really widespread popularity in China. For those people who have already invested the online shopping business. If you understand the Chinese consumer buying behavior can develop better marketing strategies for businesses. For multinational corporations, if the business can understand Chinese electronic consumer buying behavior and psychology. After they enter the Chinese e-commerce market, this information can increase the likelihood of business success.

This thesis can help the online shop owners to identify the key improvement parts in their business and also can focus them to help that in order to enhance they customers' satisfaction and loyalty about online shopping in China.

This research can help the online owners in China in those following way:

1. For the impact on convenience about online customers `shopping intention in China.

2. For the impact on website design/feature about online customers` shopping intention in China.

3. For the impact on time saving about online customers` shopping intention in China.

4. For the impact on security about online customers`shopping intention in China.

\section{I.5 Significance of the Study}

This study will thinking about both of the consumers, business owners and businesses in the different industry not just in China. Also can be use in other countries as well. This study also can be helping those market scholars who are studying the consumer's behavior and psychology in online business in China.

Finally, this study can be benefit for the future scholars in the online shopping business, economics education and the people who benefit from the e-commerce.

The major contribution of this thesis is that show the improved understanding of the customers" decision-making process as this relates to the online shopping decisions in China's e-commerce business. The theoretical research papers of these factors have the influence to the consumer" decision to shopping online has developed for this study. From the information obtained in the empirical analysis will help people research on consumer behavior and psychology in the future of e-commerce industries. In addition, this contribution is particularly important because research on online shopping behavior of Chinese consumers is very helpful.

From a practical point of view, this study provides valuable insights. Including e-commerce and online shopping for Chinese consumers decide factors. This information can help marketers and retailers to develop appropriate marketing strategies to retain existing customers and attract new customers.

\section{I.6 Theoretical Framework}

Based on the previous studies (detail information is showed in chapter II), there are several factors impact online customers`shopping intention in China. The researcher chooses some of them and conducts the figure as follows: 


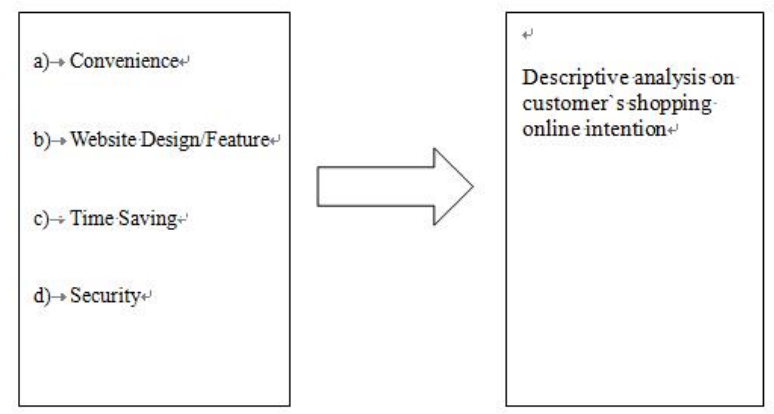

\section{I.7 Scope and Limitation of the Study}

The study was students' perceptions of Chinese consumers. Because there are many problems of the market, this study focuses on consumer satisfaction, behavioural, psychological and industry position. The results of this study only from books and magazines, and a questionnaire survey was conducted by researchers collected the raw data. This information is then considered as the factors and variables. These may have some impact to the findings.

\section{Literature Review}

\section{II.1 Introduction to Retail Business Industry}

\section{II.1.1 Definition of Retail business and E-commerce}

Retail is the sale of goods and services from individuals or businesses to the end-user. Retailers are part of an integrated system called the supply chain. A retailer purchases goods or products in large quantities from manufacturers directly or through a wholesale, and then sells smaller quantities to the consumer for a profit. Retailing can be done in either fixed locations like stores or markets, door-to-door or by delivery. Retailing includes subordinated services, such as delivery. The term "retailer" is also applied where a service provider services the needs of a large number of individuals, such as for the public. Shops may be on residential streets, streets with few or no houses or in a shopping mall. Shopping streets may be for pedestrians only. Sometimes a shopping street has a partial or full roof to protect customers from precipitation. Online retailing, a type of electronic commerce used for business-to-consumer (B2C) transactions and mail order, are forms of non-shop retailing. (wikiped, 2013)

Electronic commerce is a type of industry where the buying and selling of products or services is conducted over electronic systems such as the Internet and other computer networks. Electronic commerce draws on technologies such as mobile commerce, electronic funds transfer, supply chain management, Internet marketing, online transaction processing, electronic data interchange (EDI), inventory management systems, and automated data collection systems. Modern electronic commerce typically uses the World Wide Web at least at one point in the transaction's life-cycle, although it may encompass a wider range of technologies such as e-mail, mobile devices social media, and telephones as well. (Wiliped, 2013)

\section{II.1.2 Advantages and Disadvantages of the Online Shopping}

Today with the internet so readily accessible to us, more and more people are turning to online shopping for all their needs. Clothes, shoes, products, even groceries can now are purchased via the internet. A lot of pros have come from this; no waiting in lines or in traffic, you can shop from the convenience of your home, easier to do comparison shopping, discounts. You can shop at any time, etc. We all know we have our own reasons for shopping online. Online furniture stores are also increasing in popularity, and will continue to increase as the internet grows. Many people even purchase their sofas and other home furnishing from the comfort of their home now. With that said, here is some food for thought before you click and buy. (Ali, 2010)

\section{Advantages of online shopping}

While the shopping method has its own advantages, online shopping can be attributed to handy, all time convenience. The various advantages of online shopping are:

A) It reduce the need for shopping in the store, you can save time and energy consumption.

B) Because it is Internet sales, so we can save store expenses and other expenses. And the products and services can be a cheaper price.

C) The customer can experience shopping in a comfortable home.

D) When shopping online, you can now easily compare prices and product information. 
E) We can refer to other users of the product evaluation and comments

F) The product information can be easily viewed online.

G) There are no limit business hours to shopping, whatever what day or what is the time.

\section{Disadvantages of online shopping}

A) When the customer after purchase, they cannot be directly used. Customers need to wait for some time.

B) Customers need to bear the part of the shipping costs.

C) The customer may receive a damaged product. Products may be damaged in transit.

D) The online banking payment system security risks.

\section{II.2 Definition of Terms}

E-commerce refers to the buying, selling, marketing, and servicing of products or services over computer networks. (www.encyclopedia.com, 2012) Basically, the information technology industry might explain it as an electronic business application aimed at commercial transactions. Another definition of e-commerce can be show it as the manner of business commercial communications and management through electronic methods, also like electronic data exchange and automated data-collection systems.

In fact, it has a great impact on the production, exchange, distribution, consumer products and services to the economic phenomenon. William Daley, Secretary of Commerce in the United States, he said, "While these numbers are still small relative to the overall economy, they are becoming more and more rapidly and now have more evidence that e-commerce will be the engine economic growth in the next century. "

2011 China online retail market transactions reached 801.9 billion yuan, the market has increased $56 \%$. (Taobao, 2012) Traditional retail and e-commerce influence each other and coexist became the fact.

By understanding e-commerce, we can distinguish between the activities of traditional online retail and trade activities. China has just started to develop e-commerce. We share a relatively clear, formal, practical definition, this is crucial. This definition will guide the policy of the Chinese e-commerce development.

\section{II.3 Background on E-Commerce}

Web based e-commerce saw its early beginnings in the mid 1990's. The archetype of business's trying to expand their sales into the world of e-commerce has traditionally been characterized by a company selling their products and services to consumers through a company website. This archetype has indeed been proven successful as this method of retailing has become accepted, even demanded, by the general public and is now deemed more of a conventional retail practice than a cutting edge service being offered to consumers by a company. (DU, 2012)

E-commerce is not immune to evolution and many different avenues for conducting e-retail have emerged. Third party sites that provide price points and details of similar products from various websites in response to a consumers search have become viable forms of business, as this practice appeals to many consumers desire for a place where they can do one-stop comparison shopping. Auction sites where new and used items are sold to the highest bidder have also proven themselves to be profitable forms of business. (Liao, 2012)

However, as the manner in which people interact with the internet changes, this change creates new and exciting opportunities for e-commerce. Those with the insight to identify and tap into these opportunities early on could very well stand to have their company be in an enviable position within a new e-retailing market. There are many upcoming trends and movements that have the potential to effect and make an impact on e-retailing; Online Social Networks, however, has been chosen to be the focus of this analysis. (Liao, 2012)

\section{II.4. The E-Commerce Industry in China}

China is the world's biggest Internet market. Internet World Statistics points that by the end of June, 2010, Internet users in China reached 420million, which is a 9.36\% increase from end of 2009. Every day spent online for Chinese Internet users is about 1 billion hours. This is more than double the daily total time spent in the United States. The majority of Chinese Internet users use the Internet for communication and entertainment. (Internet World Statistics, 2011)

E-commerce business in China was started in 1998, the company name is Alibaba. And the founder is Ma Yun( Jack Ma) .The business model is that business to business (B2B) and the online platform name is Alibaba.com. EBay entered into the China e-commerce market in 2003. And was following are the Amazon, Furthermore. The year 2003 was the milestone for China e-commerce. The year Alibaba launched Alipay. Alipay" vision is that give security of online payment for your pocket.

BCG reports that 8 percent of Chinese population shopped online in 2009, compared with only 3 percent in 2006. Wang notes that online shoppers in China reached 160 million by the end of 2010. Wang also states that in 2010, e-commerce activities reached 523.1 billion RMB (approximately $\$ 104.62$ billion). Presently, 
consumer to consumer marketing $(\mathrm{C} 2 \mathrm{C})$ accounts for the largest segment in the Chinese ecommerce industry. However, business-to-consumer marketing (B2C) is growing. Products such as software and DVDs were the top sellers during the early days of Chinese e-commerce. Recently, clothing, cosmetics, books and airline tickets are becoming top sellers. (DU, 2012)

Share of online transaction in total retail sales still lags behind other developed countries; yet, Chinese consumers shop more often than their counterparts in developed economies.

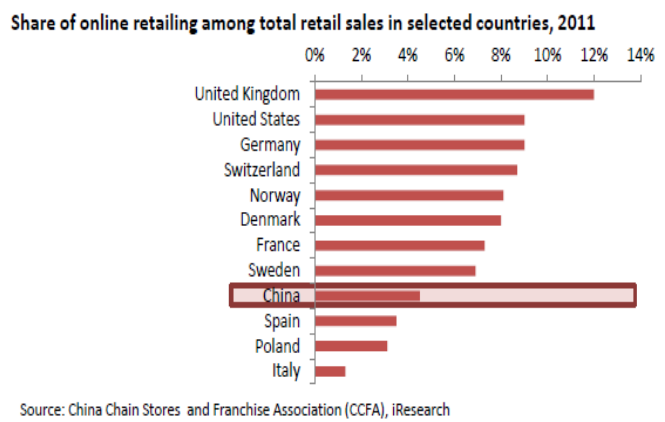

Figure 21 Share of online retailing among total retail sales

Source: China Chain Stores and Franchise Association (CCFA)

In China, online retail sales accounted for $4.3 \%$ of the total retail sales in 2011 , and are set to reach $6.3 \%$ by 2015 . The share of online transaction in total retail sales still lags behind that of other developed countries. For instance online retail sales accounted for $12 \%$ of total retail sales in the UK, $9 \%$ in the US and $9 \%$ in Germany (Li \& Fung Research Centre, 2012)

As above stats confirms internet activity as growing fast and China has always been on high heels in Internet Usage and online Shopping in Asia. According to a report on shows on the list of top 20 internet purchaser countries China is on number nine following France and Sweden. ( ACNielsen Report, 2005)

\section{II.5 Previous Studies}

Identifying the factors that influence online consumers' behavior is important as the information can help to improve the design of e-shopping websites, supporting the development of online transactions and encourage more consumers to shop online (Cao, 2005). Previous studies on consumers' online shopping behavior have identified a number of factors that consumers consider important in their adoption of online shopping. For example, Sin and Tse (2002) investigate online shopping behavior of Hong Kong consumers. The authors find that Internet shoppers and no shoppers can be distinguished by consumers' demographic, psychographic, attitudinal and experiential characteristics. They identify that in Hong Kong, educational level and income are significant discriminate variables to distinguish Internet shoppers from non- Internet shoppers. The study also finds that Internet shoppers are more familiar with the Internet and make more purchase through other in-home shopping channels. Further, the study indicates that security and reliability are two critical concerns that may prevent consumers to shop online (Tse, 2002).

Based on a survey of 214 online consumers, Ranganathan and Ganapathy (2002) find that website design characteristics, security, privacy, design, and information content are identified as the dominant factors that influence consumers' perceptions of online shopping in the U.S. Furthermore, security and privacy are found to be a more important influence on consumers' intention to shop online compare to the design and information content of the website. Alike, Shergill and Chen (2005) investigate New Zealand's online consumers' behavior and their result shows that website design, website reliability/fulfillment, website customer service, and website security/privacy are the four main factors that impact on consumers' perception on online shopping.

Using primary data from a sample of 135 respondents in India, Prasad and Aryasri (2009) identify that except trust, factors such as convenience, web store environment, online shopping enjoyment, and customer service have a significant impact on the willingness of consumers to shop on the Internet. Similarly, by using a survey of 700 New Zealand Internet users, Doolin, Dillon, Thompson, and Corner (2005) find that convenience and enjoyment of online shopping are key factors that drive consumers to purchase more via the Internet. The study also shows that the perceived risk and the loss of social interaction can prevent consumers from choosing the Internet as a shopping media.

Many studies have identified various advantages of e-shopping. Some researchers collapse these advantages together and name them perceived consequences (Limayem, 2000) and relative advantage (Langerak, 2001). Other studies utilize a more specific measurement to describe advantage of online shopping, such as effort saving, decreased transaction costs, financial benefit, and quickness (Huang, 1998). Cao and Mokhtarian (2005) point out that most of the e-shopping advantages positively influence consumers' actual online shopping intention. 
Chang and Samuel (2004) maintain that one of the vital premises, which encourage more consumers to be involved in e-commerce, is to better understand the dynamics of the consumers' decision process on the choice of online shopping. The following sections discuss factors that have been found to influence consumers' online shopping adoption behavior.

\section{II.6 Factors Influencing Consumer`s Purchasing Intention}

Though there are several factors that influence consumers to shop online, but as mentioned above researchers have selected four factors after reading literature in the field on consumer attitudes towards online shopping and these factors are discussed below in the light of previous literature.

\section{II.6.1 Convenience}

Convenience factor refers that it is easy to browse or search the information through online is easier than the traditional retail shopping. Through online, consumers can easily search product catalog but if the consumer look generally for the same product or item in a traditional store manually it is difficult to visit physically and time consuming also. Convenience has always been a prime factor for consumers to shop online. Darian mention that online shoppers carry multiple benefits in terms of convenience, such as less time consuming, flexibility, very less physical effort etc (Darian, 1987). Bhatnagar and Ghose claims for convenience as one of the most important advantage for online shopping (Ghose, 2004). According to the Robinson, Riley, Rettie and Wilsonz the major motivation for online purchasing is convince in terms of shop at any time and having bundles of items delivered at door step (Wilsonz, 2007).

Rohm and Swaminathan's claims in "typology of online shoppers into": Convenience shoppers, balanced buyers, variety seekers and store-oriented shoppers, based upon their preset shopping motivation (Swaminathan, 2004). Rohm and Swaminathan's findings about 'convenience and variety seeking' are major motivating factors of online shopping and this study is consistent with Morganosky and Cude's research findings. Web check's study shows that convenience factor is one of the biggest advantages of online shopping. Through online purchase consumers can easily compare the price than the traditional purchase. So price comparison is also another convenience factor of online shopping (Swaminathan, E-commerce, 2004).

\section{II.6.2 Website Design/Features}

Website design and online shopping activity is one of the vital influencing factors of online shopping. Website design, website reliability/fulfillment, website customer service and website security/privacy are the most attractive features which influence the perception of the consumer of online buying Shergill \& Chen (2005).

Kamariah and Salwani (2005) claims the higher website quality, the higher consumer intends to shop from internet. Web design quality has important impacts on consumer choice of electronic stores, stated by Liang and Lai (2000). Website design one of the important factor motivating consumers for online shopping. Almost 100,000 on-line shopper's surveyed by (Reibstein, 2001) shows that web site design was rated as important factor for online shopping. Another study conducted by Zhang, Dran, Small, and Barcellos (Barcellos, 1999, 2000), and Zhang and Dran (2000) indicated that website design features of the website are important and influencing factors that leads consumer's satisfaction and dissatisfaction with a specific website.

A study conducted by Yasmin and Nik (2010) shows a significant relationship between online shopping activity and website features. Website design features can be considered as a motivational factor that can create positive or negative feelings with a website. A study by Li and Zhang (2002), if website is designed with quality features it can guide the customers for successful transactions and attract the customers to revisit the website again. However, worse quality website features can also hamper online shopping. According to Liang and Lai (2000), web design quality or website features has direct impact on user to shop online.

Moreover researchers such as Belanger, Hiller and Smith (2002) concluded that a large segment of internet users have serious concerns of security.

\section{II.6.3 Time Saving}

Time savings is one of most influencing factors of online shopping. Browse or search an online catalogue can save time and patience. People can save time and can reduce effort by shopping online. According to Rohm and Swaminathan's, one possible explanation that online shopping saves time during the purchasing of goods and it can eliminate the traveling time required to go to the traditional store (Swaminathan, 2003). On the other side, some respondent think that it is also time taken for delivery of goods or services over online shopping.

Unexpectedly time saving is not the motivating factor for the consumers to shop online because it takes time receiving goods or delivery (Corbett, 2011). But time saving factor can be seen through different dimensions i.e. 
"person living in Florida can shop at Harod's in London (through the web) in less time than it takes to visit the local Burdines department store" have concluded that time saving factor was reported to be primary reason among those consumers who have already experienced the online grocery buying ((Alba et al. 1997, 2000). So the importance of the time saving factor cannot be neglected as motivation behind online purchasing. Additionally Goldsmith and Bridges emphasize that there is a discrimination between online shopper and non online shoppers, online shoppers are more worried about convenience, time saving and selection whereas non online shoppers are worried about security, privacy and on time delivery (Bridges, Goldsmith and Bridges (2000)). A study by Kamariah and Salwani shows higher website quality can highly influence customers to shop online (Salwani, Online shop, 2005).

\section{II.6.4 Security}

Security is another dominant factor which affects consumers to shop online. However many internet users avoid online shopping because of credit card fraud, privacy factors, non delivery risk, post purchase service and so on. But transaction security on the online shopping has received attention. Safe and secured transaction of money and credit card information increases trust and decreases transaction risk.

Cuneyt and Gautam claims trust in the internet shopping with advanced technology, and frequent online shopping to the internet being secured as a trustworthy shopping channel (Gautam, 2004).

\section{II.7 Purchasing Intention}

What is purchase intention? As according to business dictionary, purchase intention is defined as a plan to purchase a particular good and service in the future. According to Fishbein and Ajzen, purchase intentions are defined as decisions to act (Ajzen, 1975). As studied by Eagly and Chaiken(1993), purchase intention is defined as psychological states which represent the individual's perception to engage in a particular behaviour. According to Howard and Sheth (1967), in its simplest form, predicting purchases rests on the stage preceding actual purchase, and is referred to as "intention to purchase". There are some various theories results with, purchase intention helps predict following purchase.

\section{II.8 Online Shoppers in terms of Demography}

Online shoppers in terms of demography are another important aspect. We would like to study demography in terms of age, gender, income and education as are there any differences while consumers shop online, differences within the age groups such as does online shopping attracts elder people or younger people. Studies have shown that online shoppers mainly consist of people with Higher education and income and working in middle to senior management or professionals. Locally, a report in the Business Times and an online survey showed that demographically, a typical Net shopper is mainly male, aged between 18 and 40, had attended at least secondary school and belongs to a family with average monthly income of at least RMB5000. The online survey also showed that cyber-buyers were also mainly Chinese below 36 years old with diplomas or degrees and drawing a monthly salary of less than RMB3500. Another study by Miller (Miller, 1996) claims cyberspace is the domain of young people Bhatnagar and Ghose (Ghose, Shanqiu, 2004).

Sim and Koi states as main discriminating factors appeared to be gender and income (Koi, 2002). Customer segmentation is important for electronic commerce success. Miller has focused on demographics to show the profile of Internet users (Miller, Customer, 2010)

\section{II.9 Related Literature}

. Table 21 Brief detail regarding Previous Literature on Online Shopping

\begin{tabular}{|l|l|l|l|l|l|}
\hline No & Writers & $\begin{array}{l}\text { Research Design/ Data } \\
\text { Collection and Sample } \\
\text { frame. }\end{array}$ & $\begin{array}{l}\text { Sample Size and } \\
\text { Response Rate }\end{array}$ & Conclusion \\
Research
\end{tabular}




\begin{tabular}{|c|c|c|c|c|}
\hline & $\begin{array}{l}\text { perspective (Javidani, } \\
2010 \text { ). }\end{array}$ & & & $\begin{array}{l}\text { positive impact on attitude } \\
\text { towards online shopping in } \\
\text { Iran. } \\
\text { - The results showed that } \\
\text { Iranian users have not } \\
\text { confronted any risky } \\
\text { situations while shopping } \\
\text { online. }\end{array}$ \\
\hline 2. & $\begin{array}{l}\text { Shergill and Chen } \\
\text { Consumers Attitudes } \\
\text { towards Online } \\
\text { Shopping In New } \\
\text { Zealand (Chen, 2010). }\end{array}$ & $\begin{array}{l}\text { Non Probability and } \\
\text { convenience sampling. }\end{array}$ & $\begin{array}{l}149 \text { online shoppers } \\
\text { selected but only } 102 \\
\text { usable questionnaires } \\
\text { collected. }\end{array}$ & $\begin{array}{l}\text {-The research found one of } \\
\text { the major reasons of not } \\
\text { shopping online is security } \\
\text { issues. } \\
\text { - The study concluded that } \\
\text { many online shoppers are } \\
\text { less satisfied with website } \\
\text { design. }\end{array}$ \\
\hline 3. & $\begin{array}{l}\text { Osman, Yin-Fah and } \\
\text { Hooi-Choo } \\
\text { Undergraduates and } \\
\text { Online Purchasing } \\
\text { Behavior (Hooi-Choo, } \\
\text { 2010). }\end{array}$ & Convenience sampling & $\begin{array}{l}100 \quad \text { undergraduate } \\
\text { students were } \\
\text { selected. }\end{array}$ & $\begin{array}{l}\text {-Writers have concluded } \\
\text { that mostly students buy } \\
\text { books, cloths, travel } \\
\text { bookings and computer } \\
\text { hardware's. } \\
\text { - Website quality and } \\
\text { purchase perception have } \\
\text { significant relationship with } \\
\text { online shopping. }\end{array}$ \\
\hline 4. & $\begin{array}{l}\text { Sami Alsmadi } \\
\text { Consumer Attitudes } \\
\text { Towards Online } \\
\text { Shopping In Jordan: } \\
\text { Opportunities And } \\
\text { Challenges (Alsmadi, } \\
\text { 2002). }\end{array}$ & Convenience sampling & $\begin{array}{l}500 \text { Self administered } \\
\text { questionnaire } \\
\text { distributed in Ibrid } \\
\text { Jordan. }\end{array}$ & $\begin{array}{l}\text {-Security of online users is } \\
\text { important factor that stops } \\
\text { the willingness of online } \\
\text { purchasers. } \\
\text { - The study concluded that } \\
\text { the higher the incomer the } \\
\text { more attitude towards online } \\
\text { shopping. }\end{array}$ \\
\hline 5. & $\begin{array}{l}\text { Sarigiannidis and } \\
\text { Kesidou } \\
\text { Consumer } \\
\text { characteristics and their } \\
\text { effect on accepting } \\
\text { online shopping, in } \\
\text { context of different } \\
\text { product types (Kesidou, } \\
(2009) \text { ). }\end{array}$ & Descriptive study & $\begin{array}{l}\text { A total of } 232 \\
\text { internet users are } \\
\text { selected. }\end{array}$ & $\begin{array}{l}\text {-Product involvement } \\
\text { positively affects consumers } \\
\text { to shop online. } \\
\text { - It is concluded that privacy } \\
\text { have no effect over } \\
\text { consumers intentions } \\
\text { towards online shopping. }\end{array}$ \\
\hline
\end{tabular}

Source: Parasuraman and Grewal 


\section{III.1 Research Methods}

\section{Methodology}

This research used quantitative research methodology. Quantitative research used data that are structured in the form of numbers or that can be immediately transported in numbers (Ross, 1999). It is very controlled, exact approach to research.

Quantitative research is the systematic scientific investigation of properties and phenomena and their relationships. The objective of quantitative research is to develop and employ mathematical models, theories and/or hypotheses pertaining to natural phenomena. The process of measurement is central to quantitative research because it provides the fundamental connection between empirical observation and mathematical expression of quantitative relationships. It concerned with numbers and anything that is quantifiable. Counting and measuring are common forms of quantitative methods.

\section{III.2 Research Framework}

Based on the structure of the research, the following is a chart showing the procedure.

Figure 31 Research Framework

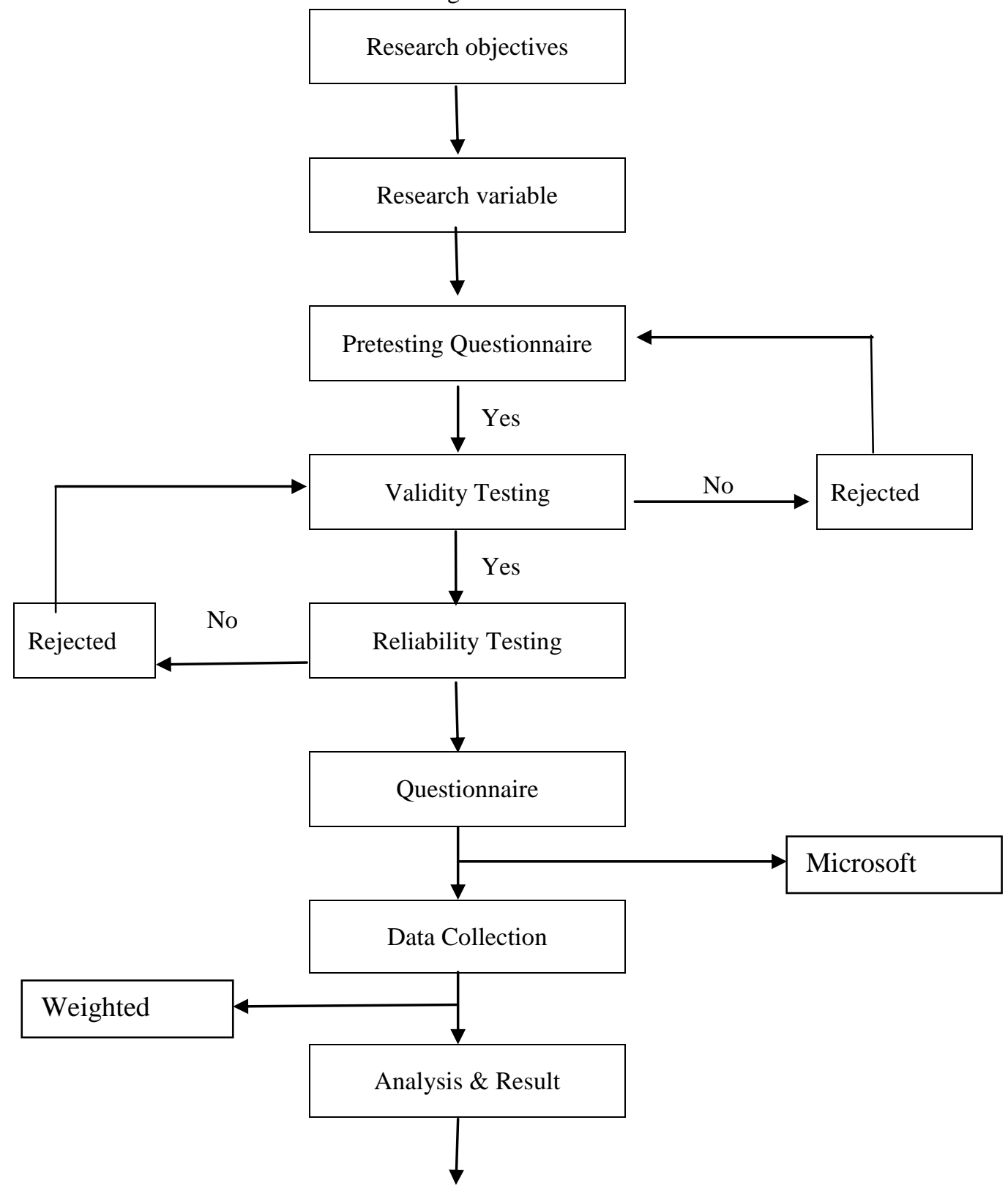




\section{Conclusion \& Recommendation}

Source: Developed by the writers for the purpose of study.

\section{III.3 Research Time and Place}

The researcher distributes the questionnaires to the responders from November 20, 2013 to November 30, 2013. The respondents for this research are the people who have experience on online shopping in china, by using the e-mail system and other communication software, the researcher who studies in Indonesia has access to distribute the questionnaire and collect the respondents on time.

\section{III.4 Demographic}

The questions in demographic part measured the age, occupation, income, gender. Almost all these questions are measured using a multiple choices method, except for ages. Participants were asked to fill in their age in the open field.

\section{III.5 Research Instruments}

In business research there are many ways in collecting primary data, such as by using interview method, focus group, discussion, observation, tests and also questionnaire. Questionnaire is a way to gather data from a portion of respondents. Questionnaire should be viewed as a multi stage process beginning with definition of the aspects to be examined and ending with interpretation of the results (Schindler, 2006).

There were several reasons why the researcher used questionnaires for this research, based on its nature, survey has several advantages.
A. Survey are relatively inexpensive(especially self-administered surveys)
B. Surveys are useful in describing the characteristics of a large population.
C. They can be administered from remote locations using mail, email or telephone.
D. Many questions can be asked about a given topic.
E. Standardized questions make measurement more precise.

Table 3.1. Operational of the Questionnaire

\begin{tabular}{|l|l|c|}
\hline Variable & \multicolumn{1}{|c|}{ Indicators } & Question No. \\
\hline \multirow{4}{*}{ Convenience } & On-time delivery & 1 \\
\cline { 2 - 3 } & Detail information is available & 2 \\
\cline { 2 - 3 } & Buy the products anytime & 3 \\
\cline { 2 - 3 } & Easy to choose and make comparison & 4 \\
\hline \multirow{5}{*}{ Website Design/Features } & Searching the products easily & 5 \\
\cline { 2 - 3 } & Safety and ease of navigation and order & 6 \\
\cline { 2 - 3 } & Searching and selecting the right product & 7 \\
\cline { 2 - 3 } & Reduce the risk of shopping online & 8 \\
\cline { 2 - 3 } & Provides me with quality of information & 9 \\
\hline \multirow{5}{*}{ Time Saving } & Takes less time to purchase. & 10 \\
\cline { 2 - 3 } & Doesn't waste time & 11 \\
\cline { 2 - 3 } & Less time in evaluating and selecting a & 12 \\
\hline \multirow{5}{*}{ product } & 14 \\
\hline & Safe and secure while shopping online & 15 \\
\cline { 2 - 3 } & Protects my security. & \\
\cline { 2 - 3 } & Trustworthy website. & 2 \\
\hline
\end{tabular}

Source: self-constructed according the theory framework 
This research used self-constructed questionnaires as an instrument to gather the data. And this questionnaire adapted from framework of variable source. These questionnaires needed to be tested. There were two kinds of tests conducted before the researcher distributed this questionnaires; validity and reliability test.

\section{III.6 Data Collection Method}

When it comes to data collection there are two methods in general used by researchers to collect data, primary and secondary method. If talking about primary data it includes observation method, Interview/ questionnaire method, case study method, projective techniques. Secondary data is one which is already collected by some other researcher not for the reason for particular study or research.

The researcher would like to go for primary data collection method that will include questionnaire from consumers as what are the factors that influence consumers to purchase online. As the study covers China online shoppers so it would be easy to distribute the questionnaire and then analyze the situation. As respondents are geographically scattered and Kumar suggests that use of questionnaire may be the only choice of data collection as if respondents are geographically scattered (Kumar, 1999).

According to Cooper and Schindler, a questionnaire is an instrument delivered to the participants via personal (telephone) or non personal (computer delivered or mail delivered) to be completed by the participants (Schindler, (2006)). A good questionnaire design is a key to obtain good survey result (Zikmund, 1994).

There are several advantages of questionnaires for the research survey.

A. Questionnaires are relatively effective and inexpensive comparing to other data collecting tool.

B. Questionnaires are powerful in presenting the characteristics of a large group of population.

C. Many standardized questions are used to increase the reliability of primary data.

This research used self-constructed questionnaires as an instrument to gather the data, the researcher constructed questionnaire based on the general accepted theory and knowledge. As the survey was self-constructed, it must be tested for validity and reliability test to prove the questions are valid and reliable.

\section{III.6.1 Validity Test}

Validity is the strength of our conclusions, inferences or propositions. More formally, Cool and Campbell define it as the "best available approximation to the truth of a given inference, proposition or conclusion (Wiliped, 2013)."

The validity of a scale may be defined as the extent to which different in observed scale scores reflect true differences among objectives on the characteristic being measured, rather than systematic or random error. There are two main things which need to get the validity testing, that are content validity and construct validity (wikiped, 2013).

A. Content validity.

Content validity refers to the adequacy with which a measure or scale has sampled from the intended universe or domain of content.

\section{B. Construct validity}

Construct validity involves testing a scale not against a single criterion but in terms of theoretically derived hypotheses concerning the nature of the underlying variable or construct. The construct validity is explored by investigating its relationship with other constructs, both related (convergent validity) and unrelated (discriminate validity).

As the questionnaire is self-conducted, the validity test should be conducted. The researcher use SPSS 19 to test the validity of questionnaire. 30 respondents from the targeted population are chosen to test the questionnaire. Following is the table from SPSS 19 software after input the data. 
Table 3.2 Result of 15 items for Validity Test

\begin{tabular}{|c|c|c|c|c|}
\hline \multicolumn{4}{|c|}{ Item-Total Statistics } & \multirow[b]{2}{*}{ status } \\
\hline & $\begin{array}{l}\text { Corrected Item-Total } \\
\text { Correlation }\end{array}$ & $\begin{array}{l}\text { Squared Multiple } \\
\text { Correlation }\end{array}$ & $\begin{array}{l}\text { Cronbach's Alpha if } \\
\text { Item Deleted }\end{array}$ & \\
\hline VAR00001 & .453 & .785 & .831 & valid \\
\hline VAR00002 & .387 & .761 & .836 & valid \\
\hline VAR00003 & .476 & .840 & .829 & valid \\
\hline VAR00004 & .420 & .779 & .834 & valid \\
\hline VAR00005 & .460 & .765 & .830 & valid \\
\hline VAR00006 & .361 & .617 & .837 & valid \\
\hline VAR00007 & .409 & .875 & .834 & valid \\
\hline VAR00008 & .560 & .869 & .824 & valid \\
\hline VAR00009 & .662 & .832 & .817 & valid \\
\hline VAR00010 & .448 & .863 & .831 & valid \\
\hline VAR00011 & .358 & .883 & .836 & valid \\
\hline VAR00012 & .362 & .561 & .837 & valid \\
\hline VAR00013 & .405 & .732 & .834 & valid \\
\hline VAR00014 & .594 & .764 & .827 & valid \\
\hline VAR00015 & .713 & .824 & .814 & valid \\
\hline
\end{tabular}

Sources: SPSS 19.0

From Table 3.2, all the 30 Corrected Item-Total Correlation is more than 0.349 based on the R-table, so they are valid, researcher can use these questions in the following research and analyze.

\section{III.6.2 Reliability}

Reliability can be assessed by internal consistency. This is degree to which the items that make up the scale are measuring the same underlying attribute (i.e. the extent to which the items "hang together"). Internal consistency can be measured in a number of ways. The most commonly used statistic is Cronbach's coefficient alpha. This statistic provides an indication of the average correlation among all of the items that make up the scale. Values range from 0 to 1 , which higher values indicating greater reliability. While different levels of reliability are required, depend on the nature and purpose of the scale, Nunnally recommends a minimum level of 0.7 (Nunnally, 1978).

Cronbach's Alpha is defined as

$$
\alpha=\frac{K}{K-1}\left(1-\frac{\sum_{i=1}^{K} \sigma_{Y_{i}}^{2}}{\sigma_{X}^{2}}\right)
$$

Where

$K$ is the number of components ( $K$-items or testlets),

$\sigma_{X \rightarrow}^{2}$ the variance of the observed total test scores,

$\sigma_{Y_{i} \text { the variance of component } i \text { for the current sample of persons. }}^{2}$

See Develles (1991)

A commonly accepted rule of thumb for describing internal consistency using Cronbach's alpha is as follows, however, a greater number of items in the test can artificially inflate the value of alpha and so this rule of thumb should be used with caution: ( http://en.wikipedia.org/wiki/Cronbach\%27s_alpha) 


$\begin{array}{ll}\text { Cronbach's alpha } & \text { Internal consistency } \\ \alpha \geq 0.9 & \text { Excellent } \\ 0.8 \leq \alpha<0.9 & \text { Good } \\ 0.7 \leq \alpha<0.8 & \text { Acceptable } \\ 0.6 \leq \alpha<0.7 & \text { Questionable } \\ 0.5 \leq \alpha<0.6 & \text { Poor } \\ \alpha<0.5 & \text { Unacceptable }\end{array}$

Result of 15 items for Reliability Test

Table 3.3 Reliability Statistics

\begin{tabular}{|r|r|}
\hline \multicolumn{2}{|c|}{ Reliability Statistics } \\
\hline Cronbach's Alpha & N of Items \\
\hline .784 & \\
\hline
\end{tabular}

Source: construed by SPSS 19

By using the SPSS, it shows the correlation between forms is 0.748 where the courseware about the research methodology showed that Cronbach`s Alpha is $0.748>0.7$ which means the data gathered through this questionnaire design are reliable.

\section{III.7 Questionnaire Design}

The questionnaire is carefully designed to meet the requirements of the research. The questions are taken from previous literature on Consumer's attitudes towards online shopping with a view to validate the research more and some of the questions are self structured to cover the diversity of research problems. The questionnaire consists of two main parts and one sub part, first part is mainly focused on questions pertaining to factors that influence consumers to shop online. Second part of the questionnaire will cover one of our research questions that are who are online shoppers in terms of demography and to see are there any difference in relation to factors that influence Chinese consumers to shop online.

\section{Part A: Factors influencing consumers to shop online}

First part of the questionnaire will cover the questions relating to factors influencing consumers to shop online, these factors are Convenience, Time Saving, Website Design/Features and Security. Convenience as one of the factor includes four questions, as mentioned above that questions are selected from previous literature and some of them are self structured. There are total of five questions pertaining to Website design/Features, three questions related to Time saving factor and three questions related to Security. All questions in this section are constructed with 5 point Likert scale ranging from 1 (strongly disagree), 3 (Neutral or not applicable) to 5 (strongly agree). There is also a subset of part A, this subset includes comments box that is left for the respondents to fill as if they feel that there are some other factors that influence consumers to shop online apart from the structured questionnaire.

\section{Part B: Demographics}

This is final section of questionnaire, as stated by Grossnickle, "easy" questions must be at the end of the questionnaire (Grossnickle, 2001). As the respondent can lose interest after answering 17 questions in the first section so that is why writers have decided to put easy questions at the end of the survey. As this section includes personal and sensitive question regarding income so as there is a risk that respondent can terminate the survey at early stage. This section includes questions pertaining to Gender, Age, Income and Education (Sam, 2003).

\section{III.8 Measurement Scale and Data Analysis}

The questionnaire used Likert scale which is developed by Rensis Likert. This scale is the most frequently used variation of summated rating scale. Summated rating scales consist of statements that express either a favorable or unfavorable attitude toward the objective of the interest. The participant is asked to agree or disagree with each statement (Schindler C. a., The questionnaire, 2006). 
In this research questionnaire the respondents are given five degrees in each question from "strongly disagree" to "strongly agree".

Table 3.4 Scale Scoring Method

\begin{tabular}{|l|l|l|l|l|l|}
\hline Answer & $\begin{array}{l}\text { Strongly } \\
\text { Disagree }\end{array}$ & Disagree & Neutral & Agree & $\begin{array}{l}\text { Strongly } \\
\text { Agree }\end{array}$ \\
\hline Score & 1 & 2 & 3 & 4 & 5 \\
\hline
\end{tabular}

Source: Adopted from Marketing Research Book, Cooper \& Schindler, 2006

\section{A. $\quad$ SPSS 19}

This computer software would be used to input the respondents' answers, testing the instrument validity and reliability, and present respondents' answers.

B. Microsoft Excel

This computer software would be used to collect the answers of questionnaire, and calculate the average.

C. Weighted mean

D. The weighted mean is known as statistical technique which enables us to calculate an average that takes into account the important of each value to the overall total. (Rubin, 1998)

The formula of weighted mean is:

$$
\overline{x_{w}}=\frac{\sum(\mathbf{w} \cdot \mathbf{x})}{\sum \cdot \text { 国 }}
$$

$\overline{x_{w}} \quad=$ symbol for the weighted mean

$\mathrm{W}=$ weight assigned to each observation

$$
\sum(w \cdot x)
$$

sum of the weight of each element times that element<smiles>C1CCC2CCCC2C1</smiles>

$=$ sum of all of the weight

Equation 2: weighted mean formula Source: Levin, and Rubin 1998, p84

The weighted mean would be used to interpret the average distribution of respondents' answers from questionnaire. The following table is the interpretation scale of the weighted mean, the basic concept of this interpretation is that people would categorize one lower option into higher value option when it has value more than 0.5 from the original designated value.

Table 3.5: scale interpretation

\begin{tabular}{|l|l|l|}
\hline Scale & Range & Description \\
\hline 1 & $1.00-1.49$ & Strongly disagree \\
\hline 2 & $1.50-2.49$ & Disagree \\
\hline 3 & $2.50-3.49$ & Neutral \\
\hline 4 & $3.50-4.49$ & Agree \\
\hline 5 & $4.50-5.00$ & Strongly agree \\
\hline
\end{tabular}

\section{III.9 Sampling Design}

As mentioned by Kent In particular research a procedure that is being followed for selecting a sampling unit is called sample design (Kent, 2007). The procedure that is being followed by the writers to select a sampling unit is a mixed process. A mixed process means distributing survey online as well as in person to online shoppers. The population selected by the writers for the study is mainly collage students in China. As 
mentioned in above paragraph writers have selected convenience sampling technique so sample is designed accordingly by approaching the students both by online survey via email system. The purpose of using the mixed process is to collect empirical data conveniently and on time, as time and resources are also kept in mind by writers at every step of this thesis.

\section{III.9.1 Size of Population}

In this research, the population is the people who have the experience of the online shopping in China.

\section{III.9.2 Sampling Technique}

In general there are two types of sampling techniques probability sampling and non probability sampling. In Probability sample there is a nonzero equal chance for each population element to be selected, Bryman and Bell. There are four types of probability sampling as stated by Bryman and Bell simple random sample, systematic sample, stratified random sampling and multi stage cluster sampling. Whereas. In non-probability sampling there is no random sampling. As stated by Bryman and Bell there are three types of non probability sampling i.e. Convenience Sampling, snowball sampling and quota sampling. According to Bryman and Bell Convenience sample is one that is conveniently available to the researcher with its goodness of accessibility. The problematic facet of this type of non probability sampling as stated by Bryman and Bell is that it is impracticable to generalize the results but at the same time in Bryman and Bell words convenience sampling more remarkable role than supposed. And as Bryman and Bell explains in business and management field this technique is more worthy as compare to sample based on probability sampling. By keeping in view the limitations of time, resources and population writers have decided to apply convenience sampling technique for the purpose of collecting empirical material. The researcher decided to distribute my questionnaire among Chinese persons, and the internet e-mail system would be helpful for the writers to approach the respondents and collect the data on time and also to avoid low response rate, as we are expecting at least $100 \%$ response rate (Bell, 2007).

By using e-mail system and other communication application, the researcher can distribute the questionnaire to them. Honestly speaking, total size of the population is around 95, including school students, parents and other internet users.

\section{III.9.3 Margin of Error}

As the respondents have already been specific and they are the Chinese people no matter graduated or not as long as they show their attitude about online retailing, therefore, the researcher uses $5 \%$ level of significance or level of confidence.

\section{III.9.4 Sampling Size}

The number of actual sample size in this research needed to represent the population, Slovin's formula allows a researcher to sample the population with a desired degree of accuracy. If a sample is taken from a population, a formula must be used to take into account confidence levels and margins of error.

Slovin's formula is written as:

$\mathrm{n}=\mathrm{N} /\left(\mathbf{1}+\mathrm{Ne}^{\wedge} \mathbf{2}\right)$

$\mathrm{n}=$ Number of samples

$\mathrm{N}=$ Total population

$\mathrm{e}=$ Error tolerance 
From above we can find out that the researcher uses 5\% level of significance or level of confidence and the total population is 95 , therefore, the sample size should be

$$
\mathbf{n}=95 /(1+95 * 0.05 * 0.05)=76.7677
$$

So the researcher will use 77 respondents as sample size.

According to Douglas, William and Robert said about the central limit theorem, "Most statisticians consider a sample of 30 or more to be large enough for the central limit theorem to be employed" (Robert, 2003).

As mentioned above (title in Sampling), the researcher uses non-probability sampling technique for the purpose of collecting material.

\section{III.10 Descriptive Analysis}

The purpose of using descriptive research is to collect actual information in detail which best describe the happening situation, to identified problem and practices, to ease in making comparison and evaluation, to determine what people respond in facing the same problem and also learn from their decision making experience to solve the same problems that might occurs in future.

Descriptive research is purposed to describe. There are no longer developing ideas, clearing up vague concept, and trying to learn something about the situation. One common focus of descriptive research is to describe characteristics of certain groups, another common use of descriptive research is to estimate the proportion of people in the population who do not something or do something (Speece, 2009).

\section{Data Analysis And Interpretation Of Results}

One of the important steps is to analyze the data and discuss the findings. In this chapter researcher will discuss the empirical findings from this study. The data analysis mainly concerns primary data collected in the form of questionnaires distributed among Chinese persons. Below table 4.1, shows the results of frequency for respondent's agreement with statements. Each statement is considered as one module.

As we showed above, five answers are:

$\mathrm{SA}=$ Strongly Agree

$\mathrm{A}=$ Agree

$\mathrm{N}=$ neutral

$\mathrm{D}=$ Disagree

$\mathrm{SD}=$ Strongly Disagree

Table 41 Respondents of the Questionnaire

\begin{tabular}{|l|r|r|r|r|r|}
\hline \multicolumn{1}{|c|}{ Modules } & SA & A & N & D & SD \\
\hline \multicolumn{1}{|c|}{ Convience } & \multicolumn{3}{|c|}{ Frequency } \\
\hline I can get on-time delivery by shopping on-line & 11 & 30 & 28 & 5 & 3 \\
\hline Detail information is available while shopping online & 10 & 22 & 33 & 8 & 4 \\
\hline $\begin{array}{l}\text { I can buy the products anytime 24 hours a day while shopping } \\
\text { online }\end{array}$ & 43 & 24 & 5 & 4 & 1 \\
\hline $\begin{array}{l}\text { It is easy to choose and make comparison with other products } \\
\text { while shopping online. }\end{array}$ & 19 & 32 & 12 & 12 & 2 \\
\hline Website Design/Features & & & & & \\
\hline The website design helps me in searching the products easily & 19 & 32 & 19 & 6 & 1 \\
\hline $\begin{array}{l}\text { While shopping online, I prefer to purchase from a website that } \\
\text { provides safety and ease of navigation and order }\end{array}$ & 40 & 23 & 10 & 2 & 2 \\
\hline $\begin{array}{l}\text { The website layout helps me in searching and selecting the right } \\
\text { product while shopping online }\end{array}$ & 22 & 37 & 9 & 7 & 2 \\
$\begin{array}{l}\text { I believe that familiarity with the website before making actual } \\
\text { purchase reduce the risk of shopping online }\end{array}$ & 24 & 34 & 11 & 7 & 1 \\
\hline $\begin{array}{l}\text { I prefer to buy from website that provides me with quality } \\
\text { information }\end{array}$ & 32 & 35 & 8 & 1 & 1 \\
\hline \multicolumn{1}{|c|}{ Time Saving } & & & & & 13 \\
\hline Online shopping takes less time to purchase. & 10 & 20 & 23 & 14 & 10 \\
\hline Online shopping doesn't waste my time & 5 & 24 & 18 & 26 & 4 \\
\hline $\begin{array}{l}\text { I feel that it takes less time in evaluating and selecting a product } \\
\text { while shopping online }\end{array}$ & & & & \\
\hline
\end{tabular}




\begin{tabular}{|c|c|c|c|c|c|}
\hline Security & & & & & \\
\hline I feel safe and secured while shopping online & 3 & 28 & 19 & 20 & 7 \\
\hline Online Shopping protects my security. & 1 & 14 & 35 & 18 & 9 \\
\hline I like to shop online from a trustworthy website. & 35 & 36 & 3 & 1 & 2 \\
\hline
\end{tabular}

Source: Data collection from researcher

Starting with the demography, data collected by the respondents in the form of age, gender, income and education, researchers will use tables and graph to see the demographic profile of online shoppers in China, in the same step researchers will do correlation analysis of each demographic factor except gender, to see the relationship with demographic factors and attitudes towards online shopping. After finishing first step, researchers will analyze 1st part of the questionnaire regarding four factors.

In the second step first section of the questionnaire will be analyzed regarding four factors influence consumers to shop online, it consist of 15 questions and each question represent one module, so in total there are 15 modules as it is evident from table 4.1. First factor that is convenience carries four modules, and each module will be analyzed and discussed separately with the help of table and graph of frequency and with results of likert scale. Writers have used five point likert scale from strongly agree with score of 5 to strongly disagree with score of 1 . The score of each module (e.g. "I get on-time delivery by shopping on-line") in terms of frequency will be used to calculate the average for each module. For instance if we denote "Strongly agree" by " 5 ", the others by "4, 3, 2, 1" then we can use the 77 input data as follows: $5 * 11$ (frequency) $+4 * 51+3 * 13+2 * 1+1 * 1$ $=301$. Divided by 77 (sample size) we will get 3,91 which is the average result for this module. In the same way we will calculate the total series for all the 15 modules. First factor that is Convenience consist of 4 modules, website design/features includes 5 modules, time saving with 3 and in the same way security as a factor consist of 3 modules. Firstly we will analyze each module separately and later on we will analyze in the form of groups (Convenience, Time saving, Website design/Features and Security). Once this part will be completed, researchers will take average of each group.

Average of each group will be calculated by taking the sum of averages of each module under each group and the dividing that sum by number of modules under each group to see trend of consumer attitudes towards online shopping. To make it more clear suppose the average score for first module (M1) is 2.5, second module (M2) is 3.5 , third module (M3) is 4.5 , fourth module (M5) is 3.7 , so the average score for convenience will be calculated by adding up the average scores $2.5+3.5+4.5+3.7=14.2$, then dividing the sum to total number of modules i.e. $14.2 / 4=3.55$.Lastly researchers will analyze question number 16 .

Question number 16 is a general question that is being asked to see if there are some other factors which affects consumers to shop online other than four factors chosen by the writers. Respondent's answers will be discussed in this section. The last section summary includes the summary about the factors that influence consumer and compare our findings with previous literature.

\section{IV.1 Demography}

Gender: According to demography profile, $66.66 \%$ respondents are male and $34.34 \%$ respondents are female. As we mentioned before the study is conducted in the Chinese people. From these groups respondents are 77. At the time of survey comparatively higher number of female said that they don't have shopping experience through online. So, according to the survey result it is clear that male respondents are more interested to shop online than female. 


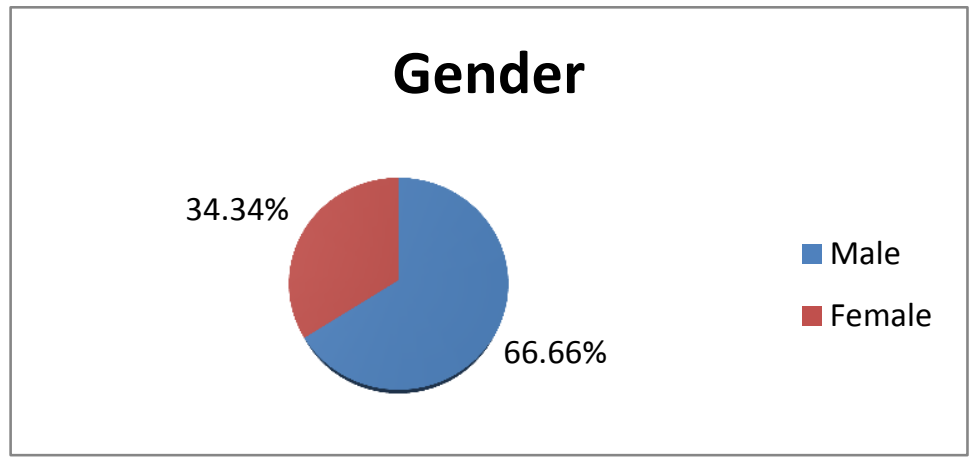

Figure 4 1Percentage of the Male and Female

Source: Developed by the writers by using Microsoft Word

Male: $66.66 \%$ Female: $34.34 \%$

Age: Below figure shows that 17\% respondents are between 15-20 years old, 55\% respondents are between 21-25 years old, 22\% respondents between 26-30 years old, 4\% respondents are between 31-35 years old, 1\%resopndents are between 36-40 years old, and 1\% respondents are above 40 years old. As we mentioned before the study is conducted among Chinese people no matter graduated or not. So according to the respondents group, maximum respondents are high school, bachelor student. Between them 55\% respondent prefer to shop online that is the highest percentage who has age limit between 21 to 25 years. Overall result shows that between all of them the respondents who has age limit between 21 to 30 years $(55 \%+22 \%=77 \%)$ people are more familiar to shop online.

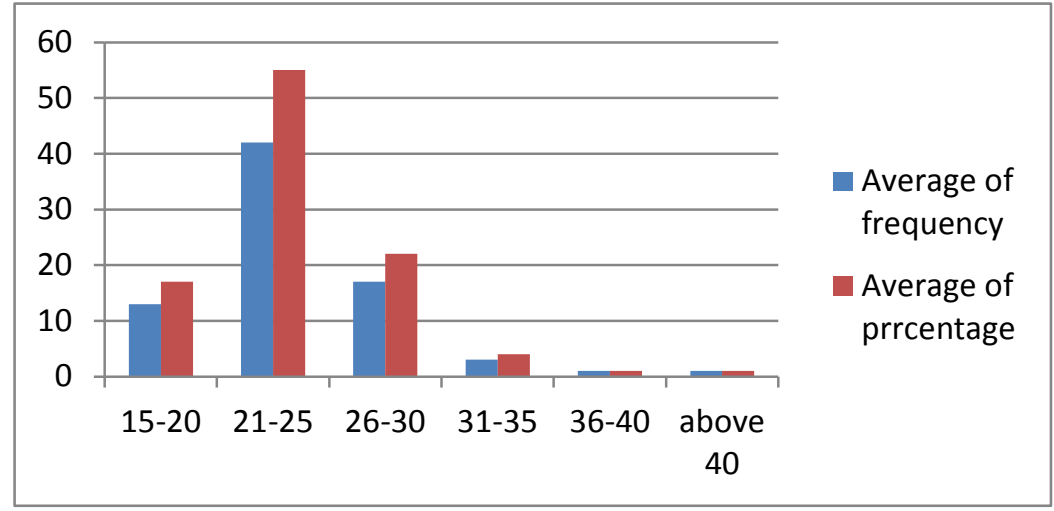

Figure 42 Frequency and Percentage of Customers`Age

Source: Developed by the writers by using Microsoft Word

Education: The study is conducted with 77 respondents, between them $74 \%$ respondents have bachelor degree or will have batcher degree lately, $25 \%$ respondents have high school degree, $1 \%$ respondents have master degree and no $\mathrm{PhD}$ respondents. From all of the respondents maximum number of respondents (2\%) is master student. Survey results shows that $98 \%$ respondents are bachelor and high school student because most of our respondents are study in the university or high school in China. 


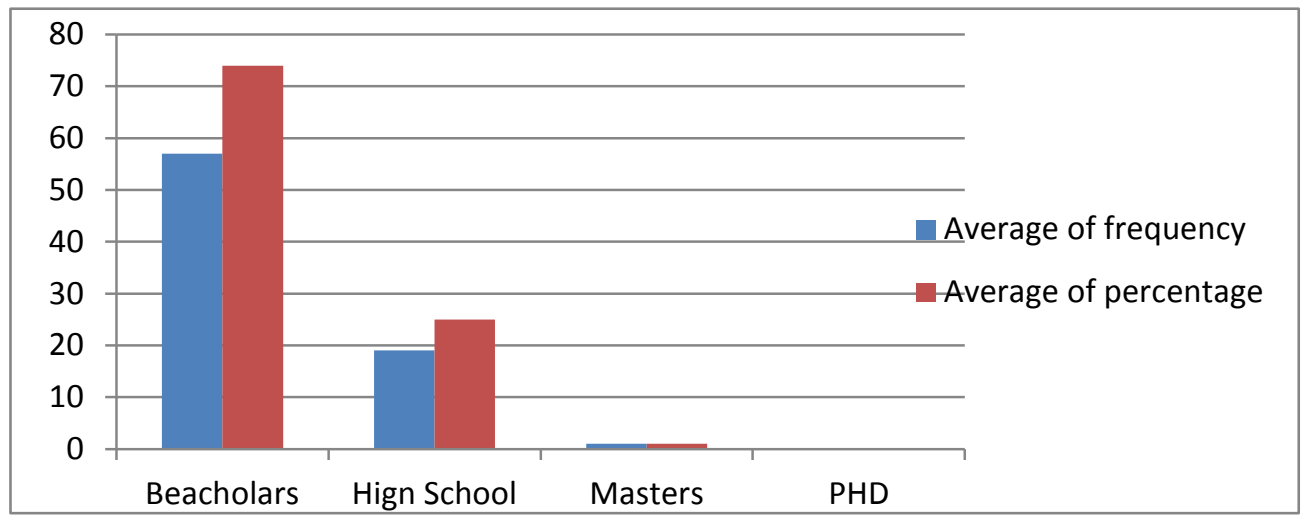

Figure 43 Frequency and Percentage of Customers`Education Degree

Source: Developed by the writers by using Microsoft Word

Income: is one of the important and sensitive demographic variables. This figure shows that $28 \%$ respondents monthly income less than $2000 \mathrm{RMB}, 40 \%$ respondents monthly income between 2001-3000 RMB, $24 \%$ respondents monthly income 3001-4000 RMB, 5\% respondents monthly income 4001-5000 RMB, only 3\% respondents monthly income more than $5000 \mathrm{RMB}$. As we mentioned before the study is conducted among the local Chinese persons no matter they graduated or not. But, I have to mention that most of the respondents are student. And for the high school student, they don't have job opportunity like the bachelor students due to knowledge, work skills and unavailability of job. Though maximum respondents are student, between them lowest number of people has good job, some students has part time job, some students get some money from parents due to their current situation, and some bachelor students they don't have higher income because they just step outside the university, lack of working experience. That is why, only $3 \%$ respondents monthly income above $5000 \mathrm{RMB}$, and $68 \%$ respondents monthly income less than $3000 \mathrm{RMB}$, between them $28 \%$ are earning less than 2000 RMB.

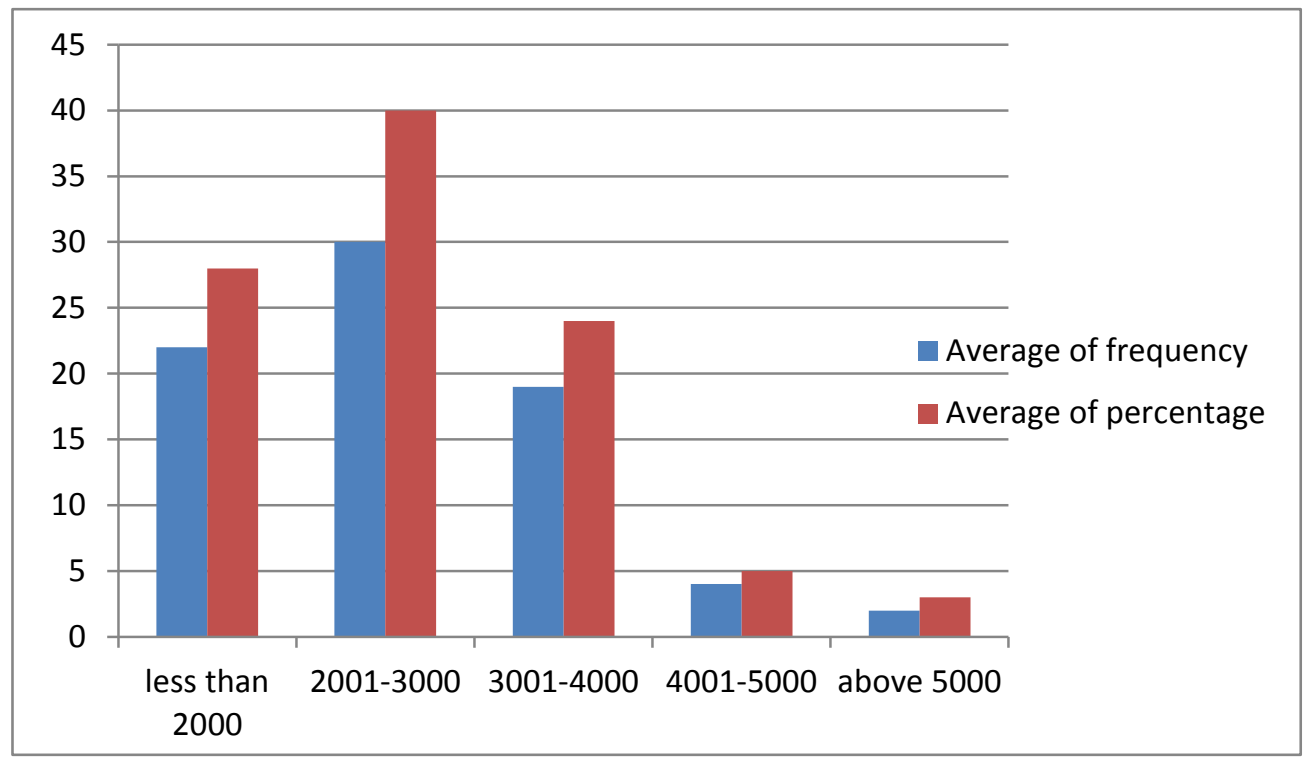

Figure 44 Frequency and Percentage of Customers`Monthly Income

Source: Developed by the writers by using Microsoft Word

\section{IV.2 Descriptive Analysis}

The descriptive analysis shows the descriptive of the questions and the frequency of respondents' answers to the questionnaire. From each indicator will describe and reflect people's opinion in convenience, website design/feature, time saving, security and buying intentions. 
Table 42 Distribution of Answers of Convenience

\begin{tabular}{|c|l|c|c|c|c|c|c|c|c|c|c|c|}
\hline & \multicolumn{7}{|c|}{ Convenience } & Ratio & total \\
\hline NO. & statement & SA & Ratio & $\mathrm{A}$ & Ratio & $\mathrm{N}$ & Ratio & $\mathrm{D}$ & Ratio & SD & Ratio \\
\hline 1 & $\begin{array}{l}\text { I can get on-time delivery } \\
\text { by shopping on-line }\end{array}$ & 11 & $14.3 \%$ & 30 & $39.0 \%$ & 28 & $36.4 \%$ & 5 & $6.5 \%$ & 3 & $3.9 \%$ & 77 \\
\hline 2 & $\begin{array}{l}\text { Detail information is } \\
\text { available while shopping } \\
\text { online }\end{array}$ & 10 & $13.0 \%$ & 22 & $28.6 \%$ & 33 & $42.9 \%$ & 8 & $10.4 \%$ & 4 & $5.2 \%$ & 77 \\
\hline & $\begin{array}{l}\text { I can buy the products } \\
\text { anytime 24 hours a day } \\
\text { while shopping online }\end{array}$ & 43 & $55.8 \%$ & 24 & $31.2 \%$ & 5 & $6.5 \%$ & 4 & $5.2 \%$ & 1 & $1.3 \%$ & 77 \\
\hline & $\begin{array}{l}\text { It is easy to choose and } \\
\text { make comparison with } \\
\text { other products while } \\
\text { shopping online. }\end{array}$ & 19 & $24.7 \%$ & 32 & $41.6 \%$ & 12 & $15.6 \%$ & 12 & $15.6 \%$ & 2 & $2.6 \%$ & 77 \\
\hline
\end{tabular}

Source: Microsoft Excel and Primary Data

From the Table 4-2, for question 1, we can see that 11 person choose strongly agree, the ratio for SA is 14.3\%. 30 persons choose agree, the ratio for $\mathrm{A}$ is $39 \%, 28$ people choose neutral, the ratio is $36.4 \%$. 5 people choose disagree, the ratio is $6.5 \%$. 3 person chooses strongly disagree, the ratio is $3.9 \%$. Based on this, we can get that 41 person give the positive comments (SA, A), the ratio is $53.3 \%$.

From the Table 4-2, for question 2, we can see that 10 person choose strongly agree, the ratio for SA is 13\%. 22 persons choose agree, the ratio for $\mathrm{A}$ is $28.6 \%, 33$ people choose neutral, the ratio is $42.9 \%$. 8 people chooses disagree, the ratio is $10.4 \%$. 4 person chooses strongly disagree, the ratio is $5.2 \%$. Based on this, we can get that 33 person give the positive comments (SA, A), the ratio is $41.6 \%$.

From the Table 4-2, for question 3, we can see that 43 person choose strongly agree, the ratio for SA is $55.8 \% .24$ persons choose agree, the ratio for $\mathrm{A}$ is $31.2 \%, 5$ people choose neutral, the ratio is $6.5 \%$. 4 people choose disagree, the ratio is $5.2 \%$. 1 person chooses strongly disagree, the ratio is $1.3 \%$. Based on this, we can get that 67 person give the positive comments (SA, A), the ratio is $87 \%$.

From the Table 4-2, for question 4, we can see that 19 person choose strongly agree, the ratio for SA is 24.7\%. 32 persons choose agree, the ratio for $\mathrm{A}$ is $41.6 \%, 12$ people choose neutral, the ratio is $15.6 \%$. 12 people choose disagree, the ratio is $15.6 \%$. 2 person chooses strongly disagree, the ratio is $2.6 \%$. Based on this, we can get that 51 person give the positive comments (SA, A), the ratio is $66.3 \%$.

Table 43 Distribution of Answers Website Design/Feature

\begin{tabular}{|c|c|c|c|c|c|c|c|c|c|c|c|c|}
\hline & \multicolumn{12}{|c|}{ website design/feature } \\
\hline NO. & statement & SA & Ratio & A & Ratio & $\mathrm{N}$ & Ratio & $\mathrm{D}$ & Ratio & SD & Ratio & total \\
\hline 5 & $\begin{array}{l}\text { The website design helps me in } \\
\text { searching the products easily }\end{array}$ & 19 & $24.7 \%$ & 32 & $41.6 \%$ & 19 & $24.7 \%$ & 6 & $7.8 \%$ & 1 & $1.3 \%$ & 77 \\
\hline 6 & $\begin{array}{l}\text { While shopping online, I prefer } \\
\text { to purchase from a website that } \\
\text { provides safety and ease of } \\
\text { navigation and order }\end{array}$ & 40 & $51.9 \%$ & 23 & $29.9 \%$ & 10 & $13.0 \%$ & 2 & $2.6 \%$ & 2 & $2.6 \%$ & 77 \\
\hline 7 & $\begin{array}{l}\text { The website layout helps me in } \\
\text { searching and selecting the right } \\
\text { product while shopping online }\end{array}$ & 22 & $28.6 \%$ & 37 & $48.1 \%$ & 9 & $11.7 \%$ & 7 & $9.1 \%$ & 2 & $2.6 \%$ & 77 \\
\hline 8 & $\begin{array}{l}\text { I believe that familiarity with the } \\
\text { website before making actual } \\
\text { purchase reduce the risk of } \\
\text { shopping online }\end{array}$ & 24 & $31.2 \%$ & 34 & $44.2 \%$ & 11 & $14.3 \%$ & 7 & $9.1 \%$ & 1 & $1.3 \%$ & 77 \\
\hline 9 & $\begin{array}{l}\text { I prefer to buy from website that } \\
\text { provides me with quality } \\
\text { information }\end{array}$ & 32 & $41.6 \%$ & 35 & $45.5 \%$ & 8 & $10.4 \%$ & 1 & $1.3 \%$ & 1 & $1.3 \%$ & 77 \\
\hline
\end{tabular}

Source: Microsoft Excel and Primary Data

From the Table 4-3, for question 5, we can see that 19 person choose strongly agree, the ratio for SA is 24.7\%. 32 persons choose agree, the ratio for $\mathrm{A}$ is $41.6 \%, 19$ people choose neutral, the ratio is $24.7 \%$. 6 people choose disagree, the ratio is $7.8 \%$. 1 person chooses strongly disagree, the ratio is $1.3 \%$. Based on this, we can get that 51 person give the positive comments (SA, A), the ratio is $66.3 \%$.

From the Table 4-3, for question 6 , we can see that 40 person choose strongly agree, the ratio for SA is $51.9 \% .23$ persons choose agree, the ratio for $\mathrm{A}$ is $29.9 \%, 10$ people choose neutral, the ratio is $13.0 \% .2$ people choose disagree, the ratio is $2.6 \%$. 2 person chooses strongly disagree, the ratio is $2.6 \%$. Based on this, we can get that 63 person give the positive comments (SA, A), the ratio is $81.8 \%$.

From the Table 4-3, for question 7, we can see that 22 person choose strongly agree, the ratio for SA is 28.6\%. 37 persons choose agree, the ratio for $\mathrm{A}$ is $48.1 \%, 9$ people choose neutral, the ratio is $11.7 \%$. 7 people 
choose disagree, the ratio is $9.1 \% .2$ person chooses strongly disagree, the ratio is $2.6 \%$. Based on this, we can get that 59 person give the positive comments (SA, A), the ratio is $76.7 \%$.

From the Table 4-3, for question 8 , we can see that 24 person choose strongly agree, the ratio for SA is $31.2 \%$. 34 persons choose agree, the ratio for $\mathrm{A}$ is $44.2 \%, 11$ people choose neutral, the ratio is $14.3 \% .7$ people choose disagree, the ratio is $9.1 \% .1$ person chooses strongly disagree, the ratio is $1.3 \%$. Based on this, we can get that 58 person give the positive comments (SA, A), the ratio is $75.4 \%$.

From the Table 4-3, for question 9 , we can see that 32 person choose strongly agree, the ratio for SA is $41.6 \% .35$ persons choose agree, the ratio for $\mathrm{A}$ is $45.5 \%, 8$ people choose neutral, the ratio is $10.4 \%$. 1 person chooses disagree, the ratio is $1.3 \%$. 1 person chooses strongly disagree, the ratio is $1.3 \%$. Based on this, we can get that 67 person give the positive comments (SA, A), the ratio is $87.1 \%$.

Table 44 Distribution of Answers Time Saving

\begin{tabular}{|c|l|c|c|c|c|c|c|c|c|c|c|c|}
\hline & \multicolumn{10}{|c|}{ Time Saving } \\
\hline NO. & statement & SA & Ratio & A & Ratio & N & Ratio & D & Ratio & SD & Ratio & total \\
\hline 10 & $\begin{array}{l}\text { Online shopping takes less } \\
\text { time to purchase. }\end{array}$ & 13 & $16.9 \%$ & 30 & $39.0 \%$ & 18 & $23.4 \%$ & 14 & $18.2 \%$ & 2 & $2.6 \%$ & 77 \\
\hline 11 & $\begin{array}{l}\text { Online shopping doesn't } \\
\text { waste my time }\end{array}$ & 10 & $13.0 \%$ & 20 & $26.0 \%$ & 23 & $29.9 \%$ & 14 & $18.2 \%$ & 10 & $13.0 \%$ & 77 \\
\hline 12 & $\begin{array}{l}\text { I feel that it takes less time } \\
\text { in evaluating and selecting a } \\
\text { product while shopping } \\
\text { online }\end{array}$ & 5 & $6.5 \%$ & 24 & $31.2 \%$ & & $23.4 \%$ & & $33.8 \%$ & & $5.2 \%$ & 77 \\
\hline
\end{tabular}

Source: Microsoft Excel and Primary Data

From the Table 4-4, for question 10, we can see that 13 person choose strongly agree, the ratio for SA is $16.9 \%$. 30 persons choose agree, the ratio for $\mathrm{A}$ is $39 \%, 18$ people choose neutral, the ratio is $23.4 \% .14$ people choose disagree, the ratio is $18.2 \%$. 2 person chooses strongly disagree, the ratio is $2.6 \%$. Based on this, we can get that 43 person give the positive comments (SA, A), the ratio is $55.9 \%$.

From the Table 4-4, for question 11, we can see that 10 person choose strongly agree, the ratio for SA is $13 \% .20$ persons choose agree, the ratio for A is $26 \%, 23$ person choose neutral, the ratio is $29.9 \%$. 14 people choose disagree, the ratio is $18.2 \%$. 10 person chooses strongly disagree, the ratio is $13 \%$. Based on this, we can get that 30 person give the positive comments (SA, A), the ratio is $39 \% .24$ person give negative comments (D, $\mathrm{SD})$, the ratio is $31.2 \%$.

From the Table 4-4, for question 12, we can see that 5 person choose strongly agree, the ratio for SA is $6.5 \%$. 24 persons choose agree, the ratio for $\mathrm{A}$ is $31.2 \%, 18$ people choose neutral, the ratio is $23.4 \%$. 26 people choose disagree, the ratio is $33.8 \%$. 4 person chooses strongly disagree, the ratio is $5.2 \%$. Based on this, we can get that 29 person give the positive comments (SA, A), the ratio is $37.7 \% .30$ people give negative comments (D, $\mathrm{SD})$, the ratio is $39 \%$

Table 45 Distribution of Answers Security

\begin{tabular}{|c|l|c|c|c|c|c|c|c|c|c|c|c|}
\hline & \multicolumn{10}{|c|}{ Security } \\
\hline NO. & statement & SA & Ratio & A & Ratio & N & Ratio & D & Ratio & SD & Ratio & total \\
\hline 13 & $\begin{array}{l}\text { I feel safe and secured } \\
\text { while shopping online }\end{array}$ & 3 & $3.9 \%$ & 28 & $36.4 \%$ & 19 & $24.7 \%$ & 20 & $26.0 \%$ & 7 & $9.1 \%$ & 77 \\
\hline 14 & $\begin{array}{l}\text { Online Shopping protects } \\
\text { my security. }\end{array}$ & 1 & $1.3 \%$ & 14 & $18.2 \%$ & 35 & $45.5 \%$ & 18 & $23.4 \%$ & 9 & $11.7 \%$ & 77 \\
\hline 15 & $\begin{array}{l}\text { Ilike to shop online from a } \\
\text { trustworthy website. }\end{array}$ & 35 & $45.5 \%$ & 36 & $46.8 \%$ & 3 & $3.9 \%$ & 1 & $1.3 \%$ & 2 & $2.6 \%$ & 77 \\
\hline
\end{tabular}

Source: Microsoft Excel and Primary Data

From the Table 4-5, for question 13, we can see that 3 person choose strongly agree, the ratio for SA is $3.9 \%$. 28 persons choose agree, the ratio for $\mathrm{A}$ is $36.4 \%, 19$ people choose neutral, the ratio is $24.7 \%$. 20 people choose disagree, the ratio is $26 \% .7$ person chooses strongly disagree, the ratio is $9.1 \%$. Based on this, we can get that 31 person give the positive comments (SA, A), the ratio is $40.3 \%$. 27 person give the negative comments (D, SD), the ratio is $35.1 \%$.

From the Table $4-5$, for question 12 , we can see that 1 person choose strongly agree, the ratio for SA is $1.3 \%$. 14 persons choose agree, the ratio for $\mathrm{A}$ is $18.2 \%, 35$ people choose neutral, the ratio is $45.5 \%$. 18 people choose disagree, the ratio is $23.4 \%$. 9 person chooses strongly disagree, the ratio is $11.7 \%$. Based on this, we can get that 15 person give the positive comments (SA, A), the ratio is $19.5 \% .27$ person give negative comments (D, $\mathrm{SD})$, the ratio is $35.1 \%$.

From the Table $4-5$, for question 15 , we can see that 35 person choose strongly agree, the ratio for SA is $45.5 \%$. 36 persons choose agree, the ratio for $\mathrm{A}$ is $46.8 \%, 3$ people choose neutral, the ratio is $3.9 \%$. 1 person 
chooses disagree, the ratio is $1.3 \% .2$ person chooses strongly disagree, the ratio is $2.6 \%$. Based on this, we can get that 71 person give the positive comments (SA, A), the ratio is $92.3 \%$.

Table 46 Distribution of Answers Customers` Purchasing Intention

\begin{tabular}{|c|c|c|c|c|c|c|c|c|c|c|c|c|}
\hline & \multicolumn{12}{|c|}{ Purchasing Intention } \\
\hline NO. & statement & SA & Ratio & A & Ratio & $\mathrm{N}$ & Ratio & $\mathrm{D}$ & Ratio & SD & Ratio & total \\
\hline 16 & $\begin{array}{l}\text { I intend to purchase some } \\
\text { products from the internet. in } \\
\text { two weeks time }\end{array}$ & 26 & $33.8 \%$ & 19 & $24.7 \%$ & 20 & $26.0 \%$ & 8 & $10.4 \%$ & 4 & $5.2 \%$ & 77 \\
\hline 17 & $\begin{array}{l}\text { Given a chance, I will purchase } \\
\text { products that I need from the } \\
\text { internet. }\end{array}$ & 30 & $39.0 \%$ & 15 & $19.5 \%$ & 25 & $32.5 \%$ & 5 & $6.5 \%$ & 2 & $2.6 \%$ & 77 \\
\hline
\end{tabular}

Source: Microsoft Excel and Primary Data

From the Table 4-6, for question 16, we can see that 26 person choose strongly agree, the ratio for SA is $33.8 \%$. 19 persons choose agree, the ratio for $\mathrm{A}$ is $24.7 \%, 20$ people choose neutral, the ratio is $26 \%$. 8 people choose disagree, the ratio is $10.4 \%$. 4 person chooses strongly disagree, the ratio is $5.2 \%$. Based on this, we can get that 45 person give the positive comments (SA, A), the ratio is $58.5 \%$.

From the Table 4-6, for question 17, we can see that 30 person choose strongly agree, the ratio for SA is $39 \%$. 15 persons choose agree, the ratio for $\mathrm{A}$ is $19.5 \%, 25$ people choose neutral, the ratio is $32.5 \%$. 5 people choose disagree, the ratio is $6.5 \% .2$ person chooses strongly disagree, the ratio is $2.6 \%$. Based on this, we can get that 45 person give the positive comments ( $\mathrm{SA}, \mathrm{A})$, the ratio is $58.5 \%$.

\section{IV.2.1 Convenience}

Convenience is divided into four modules, each module carries one question.

1. I get on time delivery by shopping online: As you can see in the first module that is "I get on time delivery by shopping online" if we look at the results in table 1 in appendix, $53.25 \%$ of the respondents agreed with the statement that they get on time delivery by shopping online and only $10.39 \%$ respondents are disagree with the statement. Likert scale scores are calculated by multiplying each frequency by the likert scale score ranging from $5=$ strongly agree to $1=$ strongly disagree, and then total score is divided by the sample size that is 77 to get the average score. The higher the average scores the higher the respondents' agreement with the module. In table 8 in appendix the average score is 3.35 which shows on average online shoppers in China get on time delivery by shopping online.

2. Detail information is available while shopping online: Table 2 in appendix shows that $12.99 \%$ of the respondents are strongly agree with the statement that "detail information is available while shopping online" $28.57 \%$ agree, $42.86 \%$ uncertain, $10.39 \%$ disagree and only $5.19 \%$ strongly disagree with the statement. In the table 9 if you look at the average score for this module that is 3.34 which shows a Positive agreement of respondents towards the module and Chinese online shoppers perceive that detail information is available while shopping online.

3. I can buy the products anytime 24 hours a day while shopping online: out of total 77 respondents $55.8 \%$ strongly agree with the statement that "they can buy the products anytime 24 hours a day while shopping online" whereas $31.2 \%$ agree, $6.5 \%$ showed uncertain response, $5.2 \%$ disagree and $1.3 \%$ strongly disagree as shown in table 3 in appendix. So most of the respondents $(55.8+31.2=87 \%)$ falls in agree and strongly agree with the statement which shows a positive agreement. The average score for this module is 4,35 as shown in table 10 in appendix, it shows strong positive agreement with the statement that they can buy the products anytime 24 hours a day while shopping online.

4. It is easy to choose and make comparison with other products while shopping online: The percentage scores from the table 4 shows that $24.68 \%$ of the respondents strongly agree with the statement that "it is easy to choose and make comparison with other products while shopping online, whereas $41.56 \%$ Agree, $15.58 \%$ uncertain, $15.58 \%$ disagree and $2.6 \%$ strongly disagree with above statement. Majority of the respondent's falls in strongly agree and agree. The average score i.e.3.70 show a positive agreement that Chinese online shoppers or one can say Swedish online shoppers believe that it is easy to choose and make comparison with other products while shopping online.

\section{IV.2.2 Website Design/Features}

Website design/Features are divided into five modules, each module carries one question.

5. The website design helps me in searching the products easily: Table 5 shows that $24.68 \%$ of the respondents strongly agree with the statement that "website design helps me in searching the products easily, 
$41.56 \%$ agree, $24.68 \%$ uncertain, $7.79 \%$ disagree with the statement and only $1.30 \%$ strongly disagree. If you look at the average score that is 3.81 which shows strong positive agreement with the statement that website design helps consumers in searching the products easily.

6. While shopping online, I prefer to purchase from a website that provides safety and ease of navigation and order: The percentage figures depicted in table 6 in appendix, shows that out of 77 respondents $51.9 \%$ strongly agree with the statement that "while shopping online, they prefer to purchase from a website that provides safety and ease of navigation and order, in the same manner $29.9 \%$ agree, $13.0 \%$ were uncertain, $2.6 \%$ disagree and only $1 \%$ strongly disagree. Majority of the respondents agree with this statement. Even if you look at the average score 4.26 is the highest scoring so far, which shows very strong agreement of the respondents with one of the module of website design.

7. The website layout helps me in searching and selecting the right product while shopping online: Website layout is the graphic user interface of a web page, it includes the options, search bars, tools and buttons which helps user to browse and shop easily. Results indicated that $28.57 \%$ of the respondents strongly agree with the statement that "website layout helps them in searching and selecting the right product while shopping online, where as $48.05 \%$ agree, $11.69 \%$ uncertain, $9.09 \%$ disagree and $2.60 \%$ have showed disagreement with the statement. The average score of the module as shown in table 7 in appendix 3.91 shows strong agreement with the statement, which means website layout is important element for Chinese consumers while shopping online.

8. I believe that familiarity with the website before making actual purchase reduce the risk of shopping online: Table 8 in appendix shows that $31.17 \%$ respondents strongly agree with the statement "we believe that familiarity with the website before making actual purchase reduce the risk of shopping online", 44.16\% agree with the statement. $14.29 \%$ uncertain, $9.09 \%$ disagree and only $1.30 \%$ respondents have shown strong disagreement with the statement. Average score for this module is 3.95 which again show positive result as on average most of the respondents agree that past experience with website while shopping online reduces the risk of shopping online.

9. I prefer to buy from website that provides me with quality of information: China online shoppers perceive quality of information as important attribute while shopping online, as you can see from table 9 in appendix, $41.56 \%$ of the respondents strongly agree with this module, $45.45 \%$ have shown agreement, $10.39 \%$ uncertain and only $2.60 \%$ are disagree and strongly disagree with the statement. Average score 4.25 is high which also confirm that a website that provide quality of information can influence consumers more that a website with less quality information.

\section{IV.2.3 Time Saving}

Time saving is divided into three modules; we will analyze and discuss each module individually.

10. Online shopping takes less time to purchase: Results on table 10 in appendix shows that $16.88 \%$ of the respondents strongly agree that "online shopping takes less time to purchase, $38.96 \%$ respondents agree with the statement, $23.38 \%$ uncertain, $18.18 \%$ disagree and $2.60 \%$ strongly disagree with the statement. The average score 3.49 shows that online shopping takes less time to purchase as compare to traditional shopping.

11. Online shopping doesn't waste time: scores on table 11 in appendix shows that $12.99 \%$ respondents out of 77 sample size strongly agree with the statement that "online shopping doesn't waste time", $25.97 \%$ agree, $29.87 \%$ uncertain, $18.18 \%$ disagree and only $12.99 \%$ respondents have shown strongly disagreement with the statement. The average score calculated from likert scores 3.08 shows positive agreement with the statement and it shows China online shoppers believe that online shopping doesn't waste time.

12. I feel that it takes less time in evaluating and selecting a product while shopping online: Only $6.49 \%$ respondents are strongly agreed with the statement that "it takes less time in evaluating and selecting a product while shopping online", $31.17 \%$ agree, $23.38 \%$ uncertain, $33.77 \%$ disagree, and $5.19 \%$ strongly disagree with the Statement. The average score as you can see in table 12 in appendix 3.00 but if you look at the frequency and percentage of respondents $38.96 \%$ disagree and $23.38 \%$ uncertain which mean product evaluation takes less time but not so much less.

\section{IV.2.4 Security}

Security is divided into three modules and each module carries one question.

13. I feel safe and secure while shopping online: Table 13 in appendix indicates that $3.90 \%$ respondents strongly agree, $36.36 \%$ agree, $24.68 \%$ uncertain, $25.97 \%$ disagree and $9.09 \%$ respondents strongly disagree with the statement that "they feel that online shopping protects their security". The average score is 3.00 , which 
shows that on average respondents are uncertain that they feel Safe and secure while shopping online. As $50.65 \%$ of the respondents fall between disagree and uncertain which also show that online shoppers in China have security issues while shopping online.

14. Online Shopping protects my security: Table 14 in appendix indicates quite negative trend, only $18.48 \%$ respondents fall between strongly agree and agree, $45.45 \%$ are uncertain, $23.38 \%$ are disagree and $11.69 \%$ respondents strongly disagree with the statement that "online shopping protects their security". Even the average score is less than 3.0 that is 2.74 , which shows declining trend, by interpreting the statement and results one gets to know that online shopping security is important aspect which negatively influence consumers to shop online.

15. I like to shop online from a trustworthy website: Table 15 in appendix indicates $45.45 \%$ of the respondents strongly agree that "they like to shop online from trust worthy website", $46.75 \%$ agree with this statement which mean in total out of $77,92.21 \%$ respondents believes that trustworthiness is important attribute while shopping online. If you look as the average score that is 4.31 which also proves that majority of the respondents would not like to take risk by shopping from a website that is not trustworthy.

\section{IV.3 Comparative Analysis of Four Factors}

In the comparative analysis of four factors we will take the averages of each factor by their corresponding modules, for instance "Convenience" as one of the four factors contains four modules, we will take the average of four modules under convenience and compare with other factors averages to see which factor is relatively more attractive, we will also discuss the each factor as well. In table 16 in appendix you can see Convenience contains 4 modules, Website design/ Features contains 5 modules, Time saving with 3 modules and Security contains 3 modules. The average score for convenience is 3,95 which is high score and it indicates convenience is the important factor for online shoppers in China and convenience as a factor influence consumers to shop online and it also attracts online shoppers, if we compare the convenience with the other factors it has second highest score and this also indicates as it is one of the important factor for online shoppers in China, as it is an Island and there are not so many options for people in China, so it is perhaps more convenient for people to shop online.

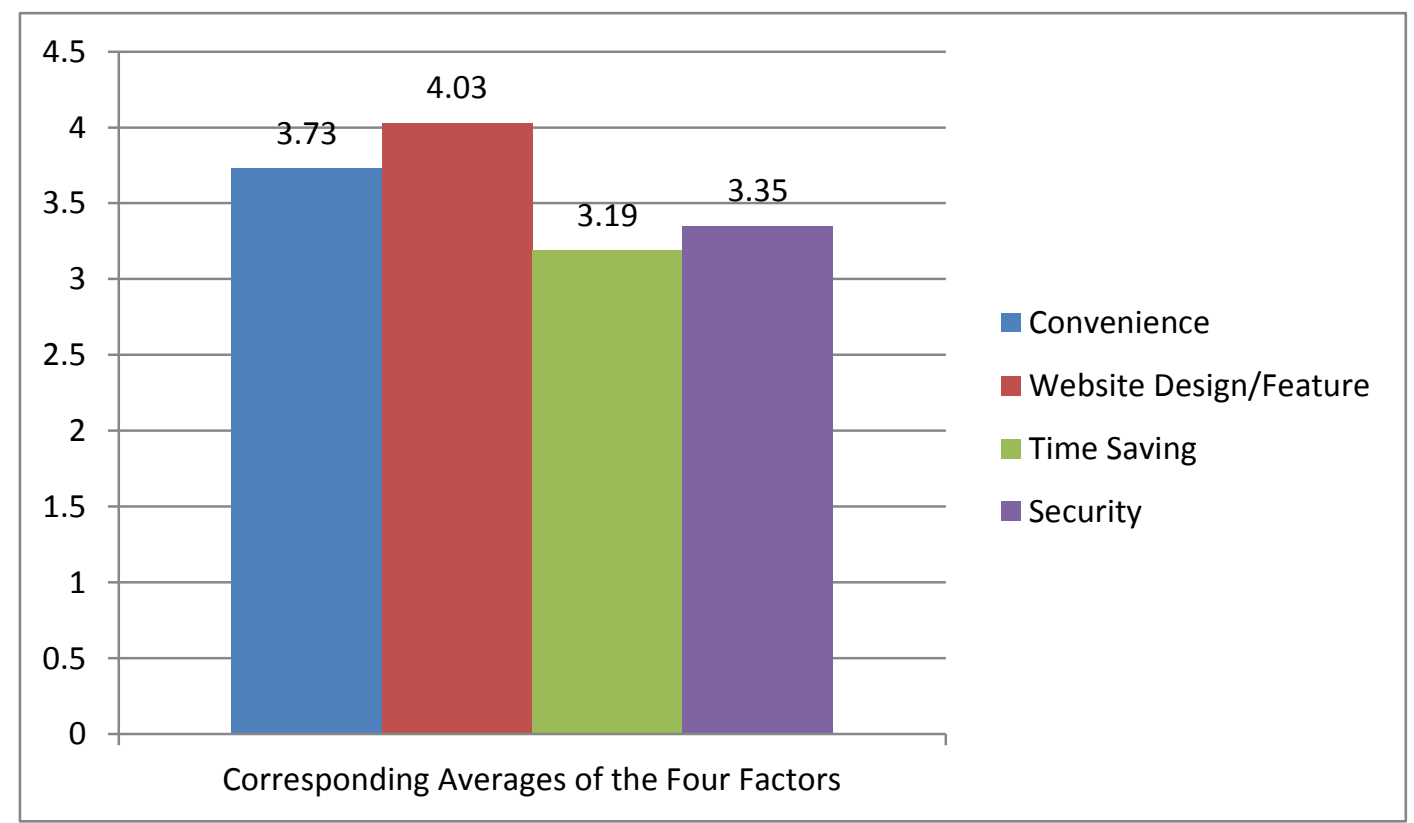

Figure 4.5 Corresponding Averages of the Four Factors

Source: Developed by the writers by using Microsoft Word

The corresponding average scores of Website Design/Features is 4,03 which the highest score we have received as compare to other factors, so it is concluded that for online shoppers in China website design/Features is the most attractive factor that influence consumers to shop online. Though time saving has the lowest score of all 3.19 but still the score is positive and it indicates that time saving is also an attractive factor 
for online shoppers in China. Lastly the average score for the security 3.35 is also positive and above 3, which shows security is an important factor that online shoppers keep in mind while shopping online.

\section{IV.4 Analysis of Additional Comments by Respondents}

Question no.16 of the study was designed to check what other factors influence consumers to shop online, out of 77 respondents, 30 respondents opted to write additional comments, summary is available in appendix 1. After analyzing the statements provided by respondents we have found another important attribute that is price of the product or services and discount, as they perceive while shopping online they get items in lower prices and the get better discounts while shopping online. As one of the respondent said "the main benefit for me is that prices are lower in on-line shops", another said "I guess shopping online depends on the price of product, otherwise I will go myself to the shop. If the shop is far away and the product is cheaper buying it online then I will shop online otherwise $\mathrm{i}$ will prefer to go to the shop, evaluate the product properly myself and make a decision to buy or not". So by looking at these statements and some other similar statements shown in appendix 1 , one can signify that price is another important factor which influences consumers to shop online. Convenience is also important factor as our study also indicated

Feedback from previous buyers is also seen to influence online shoppers, as one of the respondent said "the feedback from previous users I found it very helpful to minimize the risk". Online shoppers are also concerned about security issue and quality and reliability of information as one respondent claims "The biggest problem I have with online shopping trusts the product quality and delivery, especially since you rely totally on second hand information someone is giving you information about the product rather than you seeing it for yourself". People are also concerned about the website design and we have also found from our study as to be the most attractive factor in our study and one respondent believes "The major influence is the display of the product. Prefer products with many pictures from different positions. So after analyzing the statements writers have found that other than four factors

A. Price and discount

B. Feedback from previous users

C. Product quality and quality

These are also important factors which influence consumers to shop online.

\section{Conclusion And Recommendation}

\section{V.1 Conclusions}

Online shopping is becoming more popular day by day with the increase in the usage of World Wide Web known as www. Understanding customer's need for online selling has become challenge for marketers. Especially understanding the consumer's purchasing intention about online shopping; Making improvement in the factors that influence consumers to shop online and working on factors that affect consumers to shop online will help marketers to gain the competitive edge over others.

From the results we have concluded that the most influencing and attractive factor among four factors is website design/features with average score of 4,03, following convenience that is second most influencing factor with average score 3,73, time saving with average score 3,19 and security with average score 3,35 is also important, particularly the security concerns are very important while shopping online. Last but not least after analyzing the additional comments made by 30 respondents out of total 77 sample size, we have found that low price, discount, feedback from precious shoppers, and quality of product and information are also considered to be important factors. 


\section{V.2 Recommendations}

Generally speaking, online shopping in china has a very good condition. According to the survey, most respondents are satisfied with the current conditions. But there still have several parts need to improve.

A. To the online retailers

In order to increase the sales and create a more comfortable online shopping environment, online retailers should pay more attention on the security or customer privacy. Give online customers a safety environment. What`s more, online retailers should classify the products more clearly, it will take less time for customers to choose the products that they like.

\section{B. To other researchers}

Other researchers could conduct more study in this field. This research is expected to help other researchers to concern deeper about the factors which influence customers`attitude towards online shopping. Encourage other researchers to think more about the barriers that affect customers to shop online.

\section{Acknowledgement}

We are fortunate move to this step. First we have to thank Mr. Suresh to pay so many attentions for our Research paper. And we would like thanks to people who supported and encouraged us from the beginning until now. And thanks for the people who help us to check this papers. Thanks for your attention. God.

First of all we want to thank all of our lectures who ever helped us, brothers and sisters to give our lives to

In the teacher's teaching, we learned how to do research, analysis, etc., that you gave us approach, pointing out the maze.

Thanks to Mr. Suresh Kumah, the lecture of research methodology in President University. He gives us the suggestions, comments, and helps me correct our paper. Friends and classmates to help stay, we collect the information, data and everything we need, thank you for your support.

Thanks to the people who give us guidance Mr. Suresh Kumah, friends, and classmates during this month and every time

Thank all the support and encouragement of our teachers, parents, and Chinese friends.

Who gave us the knowledge that we study at the University president during all lectures.

Thanks a million. We really appreciate what you've done for me these days.

\section{BIBLIOGRAPHY}

\section{Reference :}

\section{Books and Journals:}

[1]. ACNielsen Report. (2005). Global Consumer Attitudes towards Online Shopping. Yanju: ACNielsen Report.

[2]. (Alba et al. 1997Morganosky and Cudep. (2000). Motication. tokyo: Yanshi.

[3]. AjzenandFishbein. (1975). Intention. Semalang: Biaoming.

[4]. AliPervaiz. (2010). 'Online Shopping' Customer Satisfaction and Loyalty in Norway. Tongzhou: Tongheng.

[5]. AlsmadiSami. (2002). Online Shopping. Yanan: Tongheng.

[6]. Barcellos. (1999, 2000). E-commerce. Kota: HM

[7]. BellandBryman. (2007). Sampling. Singapore: Hen Press.

[8]. BridgesandGoldsmith. (Goldsmith and Bridges (2000)). Online shopping. Semalang: Yanshi.

[9]. Cao. (2005). The influence online consumers" behavior. Fengyun: Fengyun.

[10]. Chen. (2010). Online Shopping. Tongzhou: Chen.

[11]. CNNIC. (2010). 21st Internet Development Statistics Report. Beijing: CNNIC.

[12]. Corbett. (2011). Comsumer. Wuermuqi: Yanshi.

[13]. Darian. (1987). Traditional retail shoppiing. Liaodong: 1987.

[14]. DU. (2012). E-commerce time. Lushan: China Daily.

[15]. Finance week paper- iResearch. (2012). Research paper. Beijing: iResearch.

[16]. GautamandCuneyt. (2004). Internet shopping. Tongzhou: Bang.

[17]. GhoseandBhatnagar. (2004). Shanqiu. Yanji: Du.

[18]. GhoseandBhatnagar. (2004). Shopping online. Dandong: Yanbian.

[19]. Grossnickle. (2001). Questionnaire. Kota: Yanshi.

[20]. Hooi-Choo. (2010). Online Purchasing. Tongzhou: Yanshi.

[21]. HuangLiang \&Koyunc. (1998). E-shopping. Yanjiang: Jiyi.

[22]. Internet World Statistics. (2011). The E-commerce Industry in China. Sunta: Internet World Statistics.

[23]. James. (Internet). The Guardian. London: The Guardian.

[24]. JavidaniMasoud. (2010). E-commerce. Qingdao: Funv.

[25]. Kent. (2007). Sample Design. Kotay: Jishi.

[26]. Kesidou. ( (2009) ). Online Shopping. Beijing: China Daliy.

[27]. KoiandSim. (2002). Customer. Foshan: China Daily.

[28]. Kumar. (1999). Daily. Marang: Bing.

[29]. Langerak\&Verhoef. (2001). E-shopping. Linying: Shuobulai.

[30]. Li \& Fung Research Centre. (2012). The reatil in China. Yexian: Li \& Fung Research Centre. 
[31]. Liao. (2012). E-commerce statistics. Yuntai: Liao and Cheung.

[32]. Limayem\& FriniKhalifa,. (2000). E-shopping. Seyan: Wuju.

[33]. Miller. (1996). Buyers. Fuzhou: Rights.

[34]. Miller. (2010). Customer. Karawang: Internet.

[35]. Nunnally. (1978). Statistics. Tongzhou: Renmin.

[36]. Reibstein. (2001). E-commerce. Nanyang: Hengtong.

[37]. RobertandWilliam. (2003). Statistics. Tokyo: Yanshi

[38]. Ross. (1999). (Ross, 1999, citied in Faculty of Economic, 2008)Citied in Faculty of Economic. Kota: AQUAY.

[39]. RubinandLevin. (1998). Accounting. Hony: GY.

[40]. SalwaniandKamariah. ( (2005)). Online Shop. Semalang: Chongjing.

[41]. SalwaniandKamariah. (2005). Online shop. Semalang: Chongjing.

[42]. Sam. (2003). Research factors influencing customers`attitude towards online shopping in Gotland. (Research factors influencing customers`attitude towarGotland: (Research factors influencing customers` attitude towaGotland University.

[43]. Schindler. ((2006)). The day. Wody: RM.

[44]. SchindlerandCooper. (2006). Questionnaire. Kota: ANAY.

[45]. SchindlerandCooper. (2006). The questionnaire. Singapore: Singapore press.

[46]. Speece\&Holbert. (2009). Mark. London: One Press.

[47]. Swaminathan. (2003). E-commerce. Yanbian: Yanshi.

[48]. Swaminathan's. (2004). E-commerce. Yanbian: Yanshi.

[49]. SwaminathanandRohm. (2004). E-commerce. Shenyang: Jilin.

[50]. SwaminathanandRohm. (2004). E-commerce. Mohe: Yanbian.

[51]. Taobao. (2012). Taobao. Hangzhoul: alibaba.

[52]. Tse\&Sin. (2002). The influence online consumers" behavior. Yanshi: Yanshi.

[53]. wikiped. (2013). Retail. XIAN: Wikiped.

[54]. Wiliped. (2013). E-commerce. MANA: Wikiped.

[55]. WilsonzandRettie. (2007). Shopping online. Heihe: Yanjiu.

[56]. www.encyclopedia.com. (2012). E-commerce. Chenglin: Encyclopdia.

[57]. You. (2013). The E-commerce in China in the past decade. Zhengzhou: Yan Shi.

[58]. Zikmund. (1994). Questionaire. Mosi: Yanshi.

\section{Websites}

[1]. AcNielson Report (2005). " Global consumer attitudes towards online shopping", online: http://www.kr.en.nielsen.com/reports/GlobalConsumerReports.shtml, (Retrieved 2012-12-04).

[2]. DIBS Report (2010). "Full year online: http://www.ir.dibspayment.com/files/IR/uploadedFiles/eng/110307_dibsfull-yearreport2010.pdf, (Retrieved 2012-12-05).

[3]. Quantitative research: http://en.wikipedia.org/wiki/Quantitative_research (Retrieved 2012-12-05).

[4]. UCLA internet report (2001). " Surveying the digital future", online: http://live.online.se/wip/publishedarchive/ucla-internet-2001.pdf, (Retrieved 2011-21-02).

[5]. Yasmin Hassan and Nik Fadrizam Akimin Abdullah(2010) "INFLUENCING FACTORS ON CONSUMER CHOICE TOWARDS ONLINE SHOPPING",online: http://www.internationalconference.com.my/proceeding/2ndice2010_proceeding/PAPER_086_ConsumerChoice.pdf, (Retrieved 2011-04-22).

[6]. http://www.google.com/\#hl=en\&tbo=d\&sclient=psy-ab\&q=E-Commerce+Industr

$\mathrm{y}+\mathrm{in}+$ China\&oq=E-Commerce+Industry $+\mathrm{in}+$ China\&gs $\mathrm{l}=\mathrm{hp} .12 \ldots 113297.113297 .1 .114338 .1 .1 .0 .0 .0 .0 .59 .59 .1 .1 .0 .1 \mathrm{es} \% 3 \mathrm{~B} \ldots 0.0 \ldots 1 \mathrm{c} .1 . \mathrm{t}$

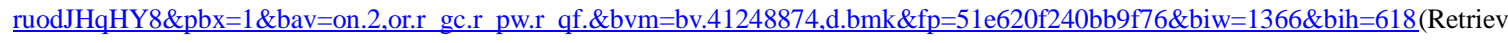
ed 2013-1-25).

[7]. http://en.wikipedia.org/wiki/Online_shopping(Retrieved 2013-1-25).

[8]. http://www.technofunc.com/index.php/domain-knowledge/retail-industry/item/overview-of-retail-industry(Retrieved 2013-1-25).

\section{APPENDIX 1 WEIGHTED MEAN}

Table 1 Analysis of question 1

\begin{tabular}{|l|l|l|l|}
\hline I get on-time delivery by shopping on-line & Likert scores & percentage \\
\hline Likert Scale & Frequency & 55 & $14.29 \%$ \\
\hline Strongly Agree & 11 & 120 & $38.96 \%$ \\
\hline Agree & 30 & 84 & $36.36 \%$ \\
\hline Neutral & 28 & 10 & $6.49 \%$ \\
\hline Disagree & 5 & 3 & $3.90 \%$ \\
\hline Strongly Disagree & 3 & & \\
\hline
\end{tabular}


The online shopping change the retail business model: A survey of the people use online shopping in

\begin{tabular}{|l|l|l|l|} 
total & 77 & 272 & $100 \%$ \\
\hline Average & & 3.53 & \\
\hline
\end{tabular}

Table 2 Analysis of question 2

\begin{tabular}{|l|l|l|l|}
\hline Detail information is available while shopping online & Likert scores & percentage \\
\hline Likert Scale & Frequency & 50 & $12.99 \%$ \\
\hline Strongly Agree & 10 & 88 & $28.57 \%$ \\
\hline Agree & 22 & 99 & $42.86 \%$ \\
\hline Neutral & 33 & 16 & $10.39 \%$ \\
\hline Disagree & 8 & 4 & $5.19 \%$ \\
\hline Strongly Disagree & 4 & 257 & $100 \%$ \\
\hline total & 77 & 3.34 & \\
\hline Average & & & \\
\hline
\end{tabular}

Table 3 Analysis of question 3

\begin{tabular}{|l|l|l|l|}
\hline I can buy the products anytime 24 hours a day while shopping online \\
\hline Likert Scale & Frequency & Likert scores & percentage \\
\hline Strongly Agree & 43 & 215 & $55.8 \%$ \\
\hline Agree & 24 & 96 & $31.2 \%$ \\
\hline Neutral & 5 & 15 & $6.5 \%$ \\
\hline Disagree & 4 & 8 & $5.2 \%$ \\
\hline Strongly Disagree & 1 & 1 & $1.3 \%$ \\
\hline total & 77 & 335 & $100 \%$ \\
\hline Average & & 4.35 & \\
\hline
\end{tabular}

Table 4 Analysis of question 4

\begin{tabular}{|l|l|l|l|}
\hline \multicolumn{4}{|l|}{ It is easy to choose and make comparison with other products while shopping online. } \\
\hline Likert Scale & Frequency & Likert scores & percentage \\
\hline Strongly Agree & 19 & 95 & $24.68 \%$ \\
\hline Agree & 32 & 128 & $41.56 \%$ \\
\hline Neutral & 12 & 36 & $15.58 \%$ \\
\hline Disagree & 12 & 24 & $15.58 \%$ \\
\hline Strongly Disagree & 2 & 2 & $2.60 \%$ \\
\hline total & 77 & 285 & $100 \%$ \\
\hline Average & & 3.70 & \\
\hline
\end{tabular}

Table 5 Analysis of question 5

\begin{tabular}{|l|l|l|l|}
\hline The website design helps me in searching the products easily \\
\hline Likert Scale & Frequency & Likert scores & percentage \\
\hline Strongly Agree & 19 & 95 & $24.68 \%$ \\
\hline Agree & 32 & 128 & $41.56 \%$ \\
\hline Neutral & 19 & 57 & $24.68 \%$ \\
\hline Disagree & 6 & 12 & $7.79 \%$ \\
\hline Strongly Disagree & 1 & 1 & $1.30 \%$ \\
\hline total & 77 & 293 & $100 \%$ \\
\hline Average & & 3.81 & \\
\hline
\end{tabular}

Table 6 Analysis of question 6

While shopping online, I prefer to purchase from a website that provides safety and ease of navigation and order

\begin{tabular}{|l|l|l|l|}
\hline Likert Scale & Frequency & Likert scores & percentage \\
\hline Strongly Agree & 40 & 200 & $51.9 \%$ \\
\hline Agree & 23 & 92 & $29.9 \%$ \\
\hline Neutral & 10 & 30 & $13.0 \%$ \\
\hline Disagree & 2 & 4 & $2.6 \%$ \\
\hline
\end{tabular}


The online shopping change the retail business model: A survey of the people use online shopping in

\begin{tabular}{|l|l|l|l|} 
Strongly Disagree & 2 & 2 & $2.6 \%$ \\
\hline total & 77 & 328 & $100 \%$ \\
\hline Average & & 4.26 & \\
\hline
\end{tabular}

Table 7 Analysis of question 7

\begin{tabular}{|c|c|c|c|}
\hline \multicolumn{2}{|c|}{ The website layout helps me in searching and selecting the right product while shopping online } \\
\hline Likert Scale & Frequency & Likert scores & percentage \\
\hline Strongly Agree & 22 & 110 & $28.57 \%$ \\
\hline Agree & 37 & 148 & $48.05 \%$ \\
\hline Neutral & 9 & 27 & $11.69 \%$ \\
\hline Disagree & 7 & 14 & $9.09 \%$ \\
\hline Strongly Disagree & 2 & 2 & $2.60 \%$ \\
\hline total & 77 & 301 & $100 \%$ \\
\hline Average & & 3.91 & \\
\hline
\end{tabular}

Table 8 Analysis of question 8

\begin{tabular}{|l|l|l|l|}
\hline \multicolumn{2}{|l|}{ I believe that familiarity with the website before making actual purchase reduce the risk of shopping online } \\
\hline Likert Scale & Frequency & Likert scores & percentage \\
\hline Strongly Agree & 24 & 120 & $31.17 \%$ \\
\hline Agree & 34 & 136 & $44.16 \%$ \\
\hline Neutral & 11 & 33 & $14.29 \%$ \\
\hline Disagree & 7 & 14 & $9.09 \%$ \\
\hline Strongly Disagree & 1 & 1 & $1.30 \%$ \\
\hline total & 77 & 304 & $100 \%$ \\
\hline Average & & 3.95 & \\
\hline
\end{tabular}

Table 9 Analysis of question 9

I prefer to buy from website that provides me with quality of information

\begin{tabular}{|l|l|l|l|}
\hline Likert Scale & Frequency & Likert scores & percentage \\
\hline Strongly Agree & 32 & 160 & $41.56 \%$ \\
\hline Agree & 35 & 140 & $45.45 \%$ \\
\hline Neutral & 8 & 24 & $10.39 \%$ \\
\hline Disagree & 1 & 2 & $1.30 \%$ \\
\hline Strongly Disagree & 1 & 1 & $1.30 \%$ \\
\hline total & 77 & 327 & $100 \%$ \\
\hline Average & & 4.25 & \\
\hline
\end{tabular}

Table 10 Analysis of question 10

\begin{tabular}{|l|l|l|l|}
\hline Online shopping takes less time to purchase. & Frequency & Likert scores & percentage \\
\hline Likert Scale & 13 & 65 & $16.88 \%$ \\
\hline Strongly Agree & 30 & 120 & $38.96 \%$ \\
\hline Agree & 18 & 54 & $23.38 \%$ \\
\hline Neutral & 14 & 28 & $18.18 \%$ \\
\hline Disagree & 2 & 2 & $2.60 \%$ \\
\hline Strongly Disagree & 77 & 269 & $100 \%$ \\
\hline total & & 3.49 & \\
\hline Average & & 28 & \\
\hline
\end{tabular}

Table 11 Analysis of question 11

\begin{tabular}{|l|l|l|l|}
\hline Online shopping doesn't waste time & Likert scores & percentage \\
\hline Likert Scale & Frequency & 50 & $12.99 \%$ \\
\hline Strongly Agree & 10 & 80 & $25.97 \%$ \\
\hline Agree & 20 & 69 & $29.87 \%$ \\
\hline Neutral & 23 & 28 & $18.18 \%$ \\
\hline Disagree & 14 & \multicolumn{2}{l}{} \\
\hline
\end{tabular}


The online shopping change the retail business model: A survey of the people use online shopping in

\begin{tabular}{|l|l|l|l|} 
Strongly Disagree & 10 & 10 & $12.99 \%$ \\
\hline total & 77 & 237 & $100 \%$ \\
\hline Average & & 3.08 & \\
\hline
\end{tabular}

Table 12 Analysis of question 12

12. I feel that it takes less time in evaluating and selecting a product while shopping online

\begin{tabular}{|l|l|l|l|}
\hline Likert Scale & Frequency & Likert scores & percentage \\
\hline Strongly Agree & 5 & 25 & $6.49 \%$ \\
\hline Agree & 24 & 96 & $31.17 \%$ \\
\hline Neutral & 18 & 54 & $23.38 \%$ \\
\hline Disagree & 26 & 52 & $33.77 \%$ \\
\hline Strongly Disagree & 4 & 4 & $5.19 \%$ \\
\hline total & 77 & 231 & $100 \%$ \\
\hline Average & & 3.00 & \\
\hline
\end{tabular}

Table 13 Analysis of question 13

\begin{tabular}{|l|l|l|l|}
\hline \multicolumn{4}{|l|}{ f feel safe and secure while shopping online } \\
\hline Likert Scale & Frequency & Likert scores & percentage \\
\hline Strongly Agree & 3 & 15 & $3.90 \%$ \\
\hline Agree & 28 & 112 & $36.36 \%$ \\
\hline Neutral & 19 & 57 & $24.68 \%$ \\
\hline Disagree & 20 & 40 & $25.97 \%$ \\
\hline Strongly Disagree & 7 & 7 & $9.09 \%$ \\
\hline total & 77 & 231 & $100 \%$ \\
\hline Average & & 3.00 & \\
\hline
\end{tabular}

Table 14 Analysis of question 14

\begin{tabular}{|l|l|l|l|}
\hline Online Shopping protects my security. \\
\hline Likert Scale & Frequency & Likert scores & percentage \\
\hline Strongly Agree & 1 & 5 & $1.30 \%$ \\
\hline Agree & 14 & 56 & $18.18 \%$ \\
\hline Neutral & 35 & 105 & $45.45 \%$ \\
\hline Disagree & 18 & 36 & $23.38 \%$ \\
\hline Strongly Disagree & 9 & 9 & $11.69 \%$ \\
\hline total & 77 & 211 & $100 \%$ \\
\hline Average & & 2.74 & \\
\hline
\end{tabular}

Table 15 Analysis of question 15

\begin{tabular}{|c|c|c|c|}
\hline Likert Scale & Frequency & Likert scores & percentage \\
\hline Strongly Agree & 35 & 175 & $45.45 \%$ \\
\hline Agree & 36 & 144 & $46.75 \%$ \\
\hline Neutral & 3 & 9 & $3.90 \%$ \\
\hline Disagree & 1 & 2 & $1.30 \%$ \\
\hline Strongly Disagree & 2 & 2 & $2.60 \%$ \\
\hline total & 77 & 332 & $100 \%$ \\
\hline Average & & 4.31 & \\
\hline
\end{tabular}

Table 16 Comparative analysis of four factors

\begin{tabular}{|l|l|l|l|l|}
\hline Comparative analysis of four factors & Security \\
\hline Modules & Convenience & Website Design/Feature & Time Saving & S \\
\hline Module 1 & 3.53 & 3.81 & 3.49 & 3 \\
\hline Module 2 & 3.34 & 4.26 & 3.08 & 2.74 \\
\hline Module 3 & 4.35 & 3.91 & 3 & 4.31 \\
\hline Module 4 & 3.7 & 3.95 & & \\
\hline Module 5 & & 4.25 & & \\
\hline
\end{tabular}




\begin{tabular}{|l|l|l|l|l|}
$\begin{array}{l}\text { Corresponding } \\
\text { Average }\end{array}$ & 3.73 & 4.03 & 3.19 & 3.35 \\
\hline
\end{tabular}

\section{Additional comments}

\begin{tabular}{|c|c|}
\hline $\begin{array}{l}\text { NO. } \\
\text { respondents }\end{array}$ & $\begin{array}{l}\text { Additional Comments (additional comments by respondents on what other factors that } \\
\text { influence them while they shop online) }\end{array}$ \\
\hline 1 & It's always easy to find good offers and even sometimes cheaper price on selected items. \\
\hline 2 & $\begin{array}{l}\text { When I shop online, I find it very important that I understand the language of the website. It is } \\
\text { also good when the websites are easy to surf in and find what you need without problems. }\end{array}$ \\
\hline 3 & makes it sometimes easy to find certain things \\
\hline 4 & Good assortment, stuff that i can't buy in usual shops and so on. \\
\hline 5 & the feedback from previous users I found it very helpful to minimize the risk \\
\hline 6 & More choice of products. \\
\hline 7 & Security \\
\hline 8 & the main benefit for me is that prices are lower in on-line shops \\
\hline 9 & $\begin{array}{l}\text { I guess shopping online depends on the price of product; otherwise I will go myself to the shop. If } \\
\text { the shop is far away and the product is cheaper buying it online then I will chop online otherwise I } \\
\text { will prefer to go to the shop, evaluate the product properly myself and make a decision to buy or } \\
\text { not }\end{array}$ \\
\hline 10 & $\begin{array}{l}\text { The biggest problem I have with online shopping trusts the product quality and delivery, } \\
\text { especially since you rely totally on second hand information i.e. someone is giving you } \\
\text { information about the product rather than you seeing it for yourself. }\end{array}$ \\
\hline 11 & Discount is obvious. \\
\hline 12 & the customer contact information \\
\hline 13 & Convenience is only the factor \\
\hline 14 & Fast and reliable shopping \\
\hline 15 & always read reviews from other consumers before shopping online \\
\hline 16 & I usually buy items in my own country online \\
\hline 17 & safety and prices \\
\hline 18 & I only use online shopping from sites, $\mathrm{i}$ have experienced with or have record is good \\
\hline 19 & I mostly shop computers or other electronic stuff online \\
\hline 20 & Price of products \\
\hline 21 & $\begin{array}{l}\text { I often check out the products in real stores before I look to see if there is a cheaper alternative } \\
\text { online so I can save money, sometimes a lot of money }\end{array}$ \\
\hline 22 & $\begin{array}{l}\text { ratings from previous customers concerning the liability of the company strongly affects me in } \\
\text { my decision to buy from them or not }\end{array}$ \\
\hline 23 & those things buy online that can only be bought online \\
\hline 24 & Discount \\
\hline 25 & usually research the thing I am buying to get the lowest price \\
\hline 26 & Good website layout really helps. \\
\hline 27 & Comments by previous customers \\
\hline 28 & Credibility of supplier prompt delivery, simple payment methods, quality of products. \\
\hline
\end{tabular}




\begin{tabular}{|l|l|}
\hline 29 & $\begin{array}{l}\text { The major influence is the display of the product. Prefer products with many pictures from } \\
\text { different positions. }\end{array}$ \\
\hline 30 & price and product quality influence me more while shopping online \\
\hline
\end{tabular}

\section{APPENDIX 2 QUESTIONNAIRE}

Questionnaire on Consumers Attitudes towards Online Shopping

Dear all: This is You Qinghe, from major Business Administration. Here I am writing my thesis for bachelor degree. By collecting your answers to analysis the factors affect customers`attitude towards online shopping. Thanks for your cooperation. This questionnaire has 15 questions and each question has 5 different answers, the answers are as follows:
1. Strongly Disagree
(SD for short)
2. Disagree
(D for short)
3. Neutral
( $\mathrm{N}$ for short)
4. Agree
(A for short)
5. Strongly Agree.
(SA for short)

And for each question, you may choose one of the answers. This questionnaire has two parts: part A and part B. part A is for the questions and part B is for additional comments.

1. Gender male

2. Age

15---20years

$21---25$ years

26---30 years

$31-40$ years

3. Income

Above 40 years

Below RMB 2000/month

2001-3000/month

3001-4000/month

4001-5000/month

Above 5500/month

4. Education

High School

Bachelors

Masters

$\mathrm{PhD}$

Part A. (Respondents are requested to an following questions with answers from strongly agree to strongly disagree on a Likert five-point scale)

NOTICE: THE QUESTIONNAIRE BELOW IS NOT FOR A SPECIFIC E-RETAILER, IT IS USED TO MEASURE THE GENERAL CONDITION.

\begin{tabular}{|l|l|l|l|l|l|l|}
\hline Modules & SA & A & N & D & SD \\
\hline Convenience & \multicolumn{2}{|l|}{ Frequency } \\
\hline 1. I can get on-time delivery by shopping on-line & & & & & \\
\hline 2.Detail information is available while shopping online & & & & & \\
\hline $\begin{array}{l}\text { 3. I can buy the products anytime 24 hours a day while } \\
\text { shopping online }\end{array}$ & & & & & \\
\hline 4. It is easy to choose and make comparison with other & & & & & \\
\hline
\end{tabular}




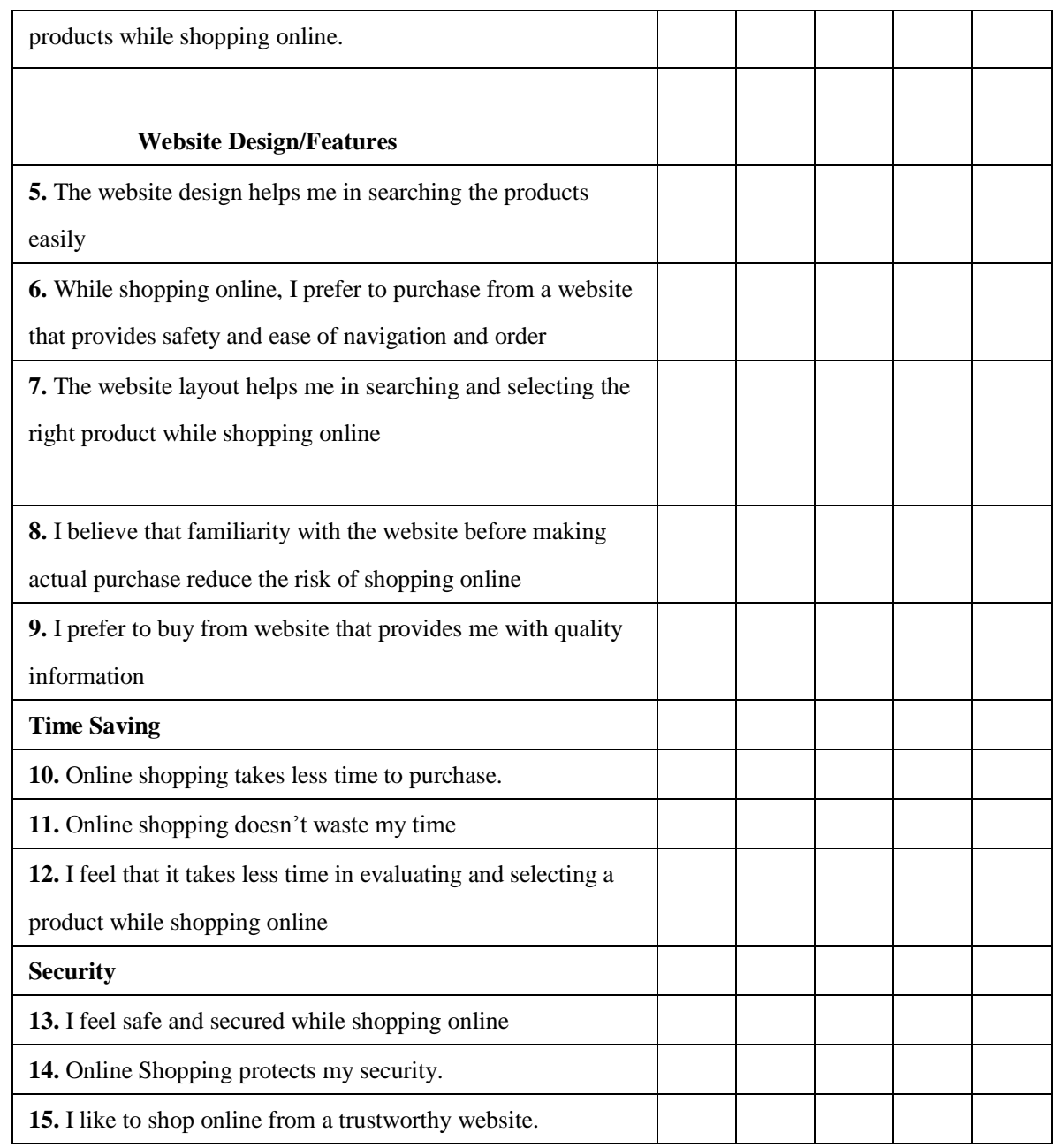

Part B (question 16). Additional Comments (In below box you can put some additional comments that influence you while you shop online)

\begin{tabular}{|l|}
\hline \\
\hline \\
\hline \\
\hline
\end{tabular}

